\title{
Cardiopulmonary imaging utilization and findings among hospitalized COVID-19 patients in Latin America \\ (From RIMAC: Registry IMAging Cardiopulmonary among hospitalized COVID-19 patients in LATAM)
}

\begin{abstract}
Authors
Salvador V Spina $\varangle$, Marcelo L Campos Vieira, César J. Herrera, Ana G. Múnera Echeverri, Pamela Rojo, Alma S Arrioja Salazar, Zuilma Y Vázquez Ortiz, Roberto Baltodano Arellano, Graciela Reyes, Rocío Aceves Millán, Juan A Calderón González, Ana C Camarozano, Edgar Avilés, Marco A Cabrera, María F Grande Ratti, Jorge Lowenstein, Rodrigo Hernández Vyhmeister, Pamela Piña Santana, Jaime A. Ibarra Burgos, Alejandra Rivera, Beatriz A Fernández Campos, Kelly M Cupe Chacalcaje, Mariela De Santos, Tania R Afonso, Tomás Miranda Aquino, Ana L Lalyre Acosta, Beatriz Domínguez, Federico Campos, Sergio M Alday Ramirez, Angela V Cachicatari Beltran, Daniela Alvarez, Patricia de Oliveira Roveri, Carlos Rosales Ixcamparij, Ender López, Pedro Vargas, Maximiliano Flores Flamand, Rosa L López Martínez, Luciana Meza, Samira Saady Morthy, Rudy Ovalle, Stalin Martínez, Oscar A Pérez Orpinel, Mauricio Potito, Otto Orellana, Jorge Marte Baez, Consuelo Orihuela Sandoval, Marcos Granillo Fernandez, Rohit Loomba, Saúl Flores, José M Hernández Hernández, Ricardo Pignatelli.
\end{abstract}

Salvador V Spina MD, Hospital Aeronáutico Central, Buenos Aires, Argentina. salvadorvspina@gmail.com Marcelo L Campos Vieira MD, Hospital Israelita Albert Einstein, São Paulo, Brazil. mluiz766@ terra.com.br César J Herrera MD, CEDIMAT, Santo Domingo, República Dominicana. cjherrera@ cedimat.net Ana G Munera Echeverri MD, Hospital General de Medellín, Medellín, Colombia. anagm@une.net.co Pamela Rojo MD, Clínica Dávila, Santiago de Chile, Chile. pamerojo@gmail.com

Alma S Arrioja Salazar MD, Clínica Dávila, Santiago de Chile, Chile. almasthelaarrioja@gmail.com Zuilma Y Vázquez Ortiz MD, Instituto Nacional de Ciencias Medicas y Nutrición "Salvador Zubirán",

Ciudad de México, Mexico.vazyur@yahoo.com.mx

Roberto Baltodano Arellano MD, HNG Almenara Irigoyen, Lima, Perú. betobaltodano97@gmail.com Graciela Reyes MD, Hospital El Cruce, Provincia Buenos Aires, Argentina. grareyes@ hotmail.com Rocío Aceves Millán MD, Centro Médico Nacional 20 de Noviembre, Ciudad de México, México. rocioacevesmillan@yahoo.es

Juan A Calderón González MD, Hospital general de Zona Número 4, Monterrey, México.

calderongonzalez@hotmail.com

Ana C Camarozano MD, Hospital Nossa Senhora das Graças y Universidade Federal do Paraná, Brazil. a.camarozano@yahoo.com.br

Edgar Avilés MD, Complejo Hospitalario Dr Arnulfo Arias Madrid, Ciudad de Panamá, Panamá.

osalocorp3@gmail.com

Marco A Cabrera MD, TECNISCAN Hospitalia, Ciudad de Guatemala, Guatemala.

drmarcocabrera@gmail.com

María F Grande Ratti,PhD, Internal Medicine Research Area, Hospital Italiano de Buenos Aires, Argentina. maria.grande@hospitalitaliano.org.ar

Jorge Lowenstein MD, Instituto de Investigaciones Médicas, Buenos Aires, Argentina.

lowensteinjorge@hotmail.com

Rodrigo Hernández Vyhmeister MD, Hospital de la Fuerza Aerea, Santiago de Chile, Chile.

rhvmd@hotmail.com

Pamela Piña Santana MD, CEDIMAT, Santo Domingo, República Dominicana. pamelapina24@gmail.com Jaime A. Ibarra Burgos MD, Medicina Interna Universidad CES, Medellín, Colombia.

iandres.jaime@uces.edu.co

Alejandra Rivera LPN, Clínica Dávila, Santiago de Chile, Chile. alerivera.palma@gmail.com

Beatriz A Fernández Campos MD, Instituto Nacional de Ciencias Medicas y Nutrición "Salvador Zubirán",

Ciudad de México, Mexico. bety1602@hotmail.com

Kelly M Cupe Chacalcaje MD, HNG Almenara Irigoyen, Lima, Perú. medalidchacalcaje@ hotmail.com

Mariela De Santos MD, Hospital El Cruce, Provincia Buenos Aires, Argentina. marielads1983@gmail.com Tania R Afonso LPN, Hospital Israelita Albert Einstein, São Paulo, Brazil. afonsotaniaregina1 @ gmail.com Tomás Miranda Aquino MD, Centro Médico Nacional 20 de Noviembre, Ciudad de México, México. tomas.miranda88@gmail.com

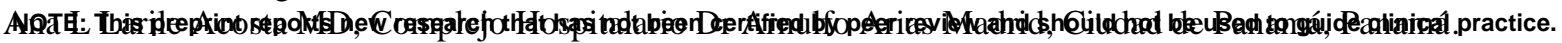
analalyre@gmail.com 
medRxiv preprint doi: https://doi.org/10.1101/2022.01.10.22269002; this version posted January 11, 2022. The copyright holder foRthis preprint (which was not certified by peer review) is the author/funder, who has granted medRxiv a license to display the preprint in

perpetuity. perpetuity.

Beatriz Domínguez MD, TECNISCAN Hospitalia, Ciudad de Guatemala, Guatemala.

drabeatrizdominguez@gmail.com

Federico Campos MD, CEDIMAT, Santo Domingo, República Dominicana. fcrosario70@gmail.com Sergio M Alday Ramírez MD, Instituto Nacional de Ciencias Medicas y Nutrición "Salvador Zubirán", Ciudad de México, Mexico. sergioalday1@ hotmail.com

Angela V Cachicatari Beltran MD, HNG Almenara Irigoyen, Lima, Perú. angie_vale00@hotmail.com Daniela Alvarez MD, Hospital El Cruce, Provincia Buenos Aires, Argentina. danielaalvarez03@hotmail.com Patricia de Oliveira Roveri MD, Hospital Israelita Albert Einstein, São Paulo, Brazil. patyroveri@ hotmail.com Carlos Rosales Ixcamparij MD, Centro Médico Nacional 20 de Noviembre, Ciudad de México, México. cixcamparij@prodigy.net.mx

Ender Otoniel González MD, TECNISCAN Hospitalia, Ciudad de Guatemala, Guatemala. enderotoniel@yahoo.es Pedro Vargas MD, CEDIMAT, Santo Domingo, República Dominicana.dr.p_vargas@ @otmail.com Maximiliano Flores Flamand MD, Instituto Nacional de Ciencias Medicas y Nutrición "Salvador Zubirán",

Ciudad de México, Mexico. max.f194@gmail.com

Rosa L López Martínez MD, HNG Almenara Irigoyen, Lima, Perú. rllopez99@ hotmail.com Luciana Meza, Technique, Hospital El Cruce, Provincia Buenos Aires, Argentina. lucianameza@live.com.ar Samira Saady Morthy MD, Hospital Israelita Albert Einstein, São Pablo, Brazil. samirasaady@ gmail.com Rudy Ovalle, Technique, TECNISCAN Hospitalia, Ciudad de Guatemala, Guatemala.ruru_mica@yahoo.com Stalin Martínez MD, CEDIMAT, Santo Domingo, República Dominicana. stalinmartinezb@gmail.com Oscar A Pérez Orpinel MD, Instituto Nacional de Ciencias Medicas y Nutrición "Salvador Zubirán", Ciudad de México, Mexico. oscperorp@hotmail.com

Mauricio Potito MD, Hospital El Cruce, Provincia Buenos Aires, Argentina. tano369@yahoo.com.ar Otto Orellana MD, TECNISCAN Hospitalia, Ciudad de Guatemala, Guatemala.

mariaveronicaespinoza@yahoo.es

Jorge Marte Baez MD, CEDIMAT, Santo Domingo, República Dominicana.j.martebaez@yahoo.com

Consuelo Orihuela Sandoval MD, Instituto Nacional de Ciencias Medicas y Nutrición "Salvador Zubirán", Ciudad de México, Mexico. c_orisan@hotmail.com

Marcos Granillo Fernandez MD, Hospital El Cruce, Provincia Buenos Aires, Argentina.

marcosgranillof@yahoo.com.ar

Rohit Loomba MD. Advocate Children's Hospital/Rosalind Franklin University of Medicine and Science, Chicago, IL, USA loomba.rohit@gmail.com

Saúl Flores MD. Texas Children's Hospital/Baylor School of Medicine, Houston, TX, USA

saul.flores2@bcm.edu

José M Hernández Hernández MD, Cardiolink Estudios Cardiovasculares, Monterrey, México.

drchemahdez@gmail.com

Ricardo Pignatelli MD, Children`s Hospital, Baylor College of Medicine, Houston, USA. cardop@ bcm.edu

Address for Correspondence:

Salvador Vicente Spina MD

Hospital Aeronáutico Central, Buenos Aires City, Argentina

Medical Director of Echocardiography. Associate Chief, Cardiology

Address: Viamonte 251, Ramos Mejía, Provincia Bs As. CP: 1704, Argentina

Telephone and WhatsApp: +5491159701093

Mailing address: salvadorvspina@gmail.com

Twitter: @ salvadorvspina

The authors declare no conflicts of interest.

\section{Fundings:}

RIMAC was designed and conducted by SISIAC (Society of Cardiovascular Images of the Inter-American Society of Cardiology). SISIAC is a non-profit academic-scientific entity that involves 23 countries throughout the Americas. It was founded in 2004 with the initial name of ECOSIAC.

This study is not sponsored by any public or private entity, nor will it have any remuneration or charge for the researchers who participate in it.

Total words: 4633.

\section{Keywords:}

Cardiopulmonary Images; SARS-CoV-2; COVID-19; LATAM; RIMAC 
medRxiv preprint doi: https://doi.org/10.1101/2022.01.10.22269002; this version posted January 11, 2022. The copyright holder foBthis preprint (which was not certified by peer review) is the author/funder, who has granted medRxiv a license to display the preprint in It is made available under a CC-BY-NC-ND 4.0 International license .

\section{Abstract}

\section{Objectives}

To describe the use and findings of cardiopulmonary imaging - chest X-ray (cX-ray), echocardiography (cEcho), chest CT (cCT), lung ultrasound

(LUS)) and/or cardiac magnetic resonance imaging (cMRI) - in COVID-19-associated hospitalizations in Latin America (LATAM)

\section{Background}

The SARS-Cov-2 is one of the largest and most active threats to healthcare in living memory. There is an information gap on imaging services resources (ISR) used and their findings during the pandemic in LATAM.

\section{Methods}

This was a multicenter, prospective, observational study of COVID-19 inpatients conducted from March to December 2020 from 12 high-complexity centers in nine LATAM countries. Adults (> 18 yrs) with at least one imaging modality performed, followed from admission until discharge and/or in-hospital death, were included.

\section{Results}

We studied 1435 hospitalized patients (64\% males) with a median age of 58 years classified into three regions: 262 from Mexico (Mx), 428 from Central America and Caribbean (CAC), and 745 from South America (SAm). More frequent comorbidities were overweight/obesity (61\%), hypertension (45\%), and diabetes (27\%). During hospitalization, $58 \%$ were admitted to ICU. The in-hospital mortality was $28 \%$ (95\%CI 25-30) highest in Mx (37\%).

The most frequent cardiopulmonary imaging performed were cCT (61\%)-more frequent in Mx and SAm-, and cX-ray (46\%) -significantly used in CAC-. The cEcho was carried out in $18 \%$, similarly among regions, and LUS in $7 \%$, more frequently in Mx. The cMRI was performed in only one patient in the cohort. Abnormal findings on the cX-ray were related to peripheral $(63 \%)$ or basal infiltrates $(52 \%)$, and in cCT with ground glass infiltrates (89\%). Both were more commonly in Mx. In LUS, interstitial syndrome (56\%) was the most related abnormal finding, predominantly in Mx and CAC.

\section{Conclusions}

The use and findings of cardiopulmonary imaging in LATAM varied between regions and may have been influenced by clinical needs, the personnel

protection measures and/or hospitalization location.

\section{Condensed Abstract}

The SARS-Cov-2 is one of the largest and most active threats to healthcare in living memory. There is limited information on imaging services resources (ISR) used and their findings during the pandemic in LATAM.

To our knowledge, RIMAC aimed the first international, multicenter study at registering the use and findings of cardiopulmonary imaging modalities performed for the diagnosis, prognosis, and treatment of patients hospitalized for infection with SARS-CoV-2 in Latin America. We studied their demographic parameters, comorbidities, in-hospital events, laboratory results, and treatments focusing on their impact in clinical complications. 
medRxiv preprint doi: https://doi.org/10.1101/2022.01.10.22269002; this version posted January 11, 2022. The copyright holder fofthis preprint (which was not certified by peer review) is the author/funder, who has granted medRxiv a license to display the preprint in

It is made available under a CC-BY-NC-ND 4.0 International license .

\author{
Abbreviations: \\ BMI: Body Mass Index \\ CAC: Central America and Caribbean region \\ cCT: chest computed tomography \\ cEcho: echocardiogram \\ cMRI: cardiac magnetic resonance imaging \\ COPD: Chronic obstructive pulmonary disease \\ cX-ray: chest R-ray \\ DBT: diabetes \\ ECG: electrocardiogram \\ FaRV: right ventricular fractional area \\ FWSRV: right ventricular free wall strain \\ GLSLV: left ventricular global longitudinal strain \\ HBP: high blood pressure \\ ICU: intensive care unit \\ IRB: institutional Review Board \\ ISR: imaging services resources \\ LUS: lung ultrasound \\ LVEF: left ventricular ejection fraction \\ MV: mechanical ventilation \\ Mx: Mexican region \\ SAm : South America region
}


medRxiv preprint doi: https://doi.org/10.1101/2022.01.10.22269002; this version posted January 11, 2022. The copyright holder fo 5 this preprint (which was not certified by peer review) is the author/funder, who has granted medRxiv a license to display the preprint in

\section{Introduction}

It is made available under a CC-BY-NC-ND 4.0 International license .

The COVID-19 pandemic is one of the largest and most active threats to healthcare in living memory. As the impact of the virus continues, systems of care around the world have responded with unprecedented protective measures.

SARS-Cov-2 predominantly affects adults, and disease severity increases with age and number of comorbidities. COVID-19 infection is mainly characterized by upper airway inflammation, which can progress into interstitial pneumonia and eventually to acute respiratory distress syndrome (ARDS) in the most severe cases. Cardiovascular complications such as thromboembolic phenomena, acute coronary syndrome, heart failure, as well as renal dysfunction are known to occur (1-4).

Cardiopulmonary imaging plays an essential role in the diagnosis of SARS-CoV-2 infection and its complications. Imaging can assess the extent of disease, prognosis, and evaluation of therapeutic interventions (1-7). Imaging services resources (ISR) such as electrocardiogram (ECG) $(8,9)$, chest X-ray (cX-ray) (10), echocardiogram (cEcho) (1114), lung ultrasound (LUS) $(15,16)$, and chest computed tomography (cCT) $(17,18)$, have been at the front line of the pandemic. Each technique offers well-known advantages; however, despite the high number of cases of infection and deaths from COVID-19, their specific application and utilization in low and middle-income countries remains unknown.

Preventive distancing and biosecurity measures during testing can protect patients and staff, thus abbreviated evaluations and imaging interventions have become the norm. RIMAC aimed at registering the use and findings of cardiopulmonary imaging modalities performed for the diagnosis, prognosis, and treatment of patients hospitalized for infection with SARS-CoV-2. We studied their demographic parameters, comorbidities, in-hospital events, laboratory results, and concomitant treatments focusing on their impact in clinical complications.

\section{Methods}

\section{Study design and patients}

We conducted a multicenter, prospective, observational study that included adult patients with SARS-Cov-2 disease admitted from March to December 2020, in 12 high-complexity centers, level III or IV, from 9 countries -Argentina, Brazil, Colombia, Chile, Guatemala, Mexico, Panama, Peru, and the Dominican Republic-, whom were divided into three geographic regions. All the centers had availability of the total imaging modalities analyzed. The total number of referral beds in each center was greater than 185, which doubled and tripled according to the needs of each region. Inclusion criteria were age $>18$ years old, positive COVID-19 CRP, and/or COVID-19 positive IgM and IgG antibodies, hospitalized status, and at least one imaging modality performed according to each treating physician`s criteria (cX-ray, cEcho, LUS, cCT, or cMRI). The cohort included a consecutive sample of patients, followed up from admission until discharge and/or in-hospital death. Patients were prospectively monitored for major complications during hospitalization.

The exclusion criteria were: patients $<18$ years old, lack of complete documentation on COVID-19 infection, non-hospitalized patients, failure to perform an imaging modality or inadequate quality for diagnosis and/or treatment (cX-ray,cEcho,LUS,cCT or cMRI).

\section{Data collection}

Patient medical records were reviewed by the research team, and data (demographic, epidemiologial, clinical, imaging, laboratory, treatment and outcome) were retriev from electronic medical records using a standardized case report form (RIMAC Registry). Data was collected and confidentially stored in a database created for this purpose; each patient was assigned a de-identifying code. Local IRB approval from each center was obtained; researchers were not involved in direct care of the subjects. The obligation to have or not 
medRxiv preprint doi: https://doi.org/10.1101/2022.01.10.22269002; this version posted January 11, 2022. The copyright holder fo6this preprint (which was not certified by peer review) is the author/funder, who has granted medRxiv a license to display the preprint in It is made available under a CC-BY-NC-ND 4.0 International license .

to have an informed consent was left to the discretion of each institution due to the nature of this study (prospective medical records review) with no intervention.

\section{Statistical analyses}

All statistical analyses were conducted using STATA (version 17.0; StataCorp, College Station, TX). Descriptive variables are presented as numbers and percentages for categorical variables; mean ( \pm standard deviation) for normally distributed continuous variables; and median (interquartile range) for non-normally distributed continuous variables.

We divided the cohort into three geographic regions for multiple comparisons. These were identified and agreed upon by the authors a priori: Mexico (Mx) as a representation of the Latin population of North America, Central America and Caribbean (CAC) that included Guatemala, Panamá, and the Dominican Republic; and South America (SAm) that included Argentina, Brazil, Chile, Colombia, and Perú.

Comparisons between regions of categorical variables were performed using Pearson's $\chi 2$ test with Bonferroni's correction. Meanwhile for continuous variables, the analysis of variance (ANOVA) or Kruskal-Wallis H test were used to compare the differences among the three groups as appropriate. In these cases of multiple comparison, only a value of $\mathrm{p} \leq 0.016$ was considered statistically significant.

Additionally, univariate and multivariate logistic regression was performed to explore the association of factors that affect the likelihood of a specific clinical imaging modality being utilized. The specific imaging modality was the dependent variable (chest computed tomography, chest X-ray, echocardiogram, and lung ultrasound). The independent variables were clinical characteristics (comorbidities prior to admission) or variables related to complications (IOT, ICU admission). The statistical significance level was set at 0.05 (two-tailed), and odds ratios (OR) and their respective 95\% confidence intervals (95\% CI) were provided.

\section{Results}

\section{Cohort overview}

Of the 1549 patients initially recruited to the registry, 114 were excluded due to a lack of complete documentation on COVID-19 infection. There were 1435 hospitalized patients (64\% males) included with a median age of 58 (SD 16.6) years: 262 from Mx, 428 from CAC, and 745 from SAm (Figure I). Figure II shows that the period of highest patient recruitment was from April to August 2020 in accordance with the first wave of COVID19 in LATAM.

A total of 708 patients (49\%) were admitted to the ward: $727(51 \%)$ patients were initially admitted to the ICU. This number subsequently increased to 836 (58\%) during total hospital stay (most were Mexican patients) and this increase normalized the differences among regions. The median number of hospitalization days was 17 (SD 17.2), and the median ICU days was 13 (SD 14.2). This is significantly lower in CAC (Table 5).

The most common comorbidities were overweight/obesity (61\%), hypertension (45\%), and diabetes $(27 \%)$. There were differences across regions: body mass index (BMI) was registered in 1180 patients, and overweight/obesity (BMI $\geq 25$ ) was significantly more prevalent in Mexico especially due to obesity -BMI $\geq 30-(42 \%)$. Hypertension (HBP) was significantly higher in CAC (60\%), and diabetes (DBT) predominated in Mx and CAC (34\%). Ischemic heart disease, chronic obstructive pulmonary disease (COPD), renal failure, and myocardiopathy were below $7 \%$ of the population (Table 1). 
medRxiv preprint doi: https://doi.org/10.1101/2022.01.10.22269002; this version posted January 11, 2022. The copyright holder for/this preprint (which was not certified by peer review) is the author/funder, who has granted medRxiv a license to display the preprint in It is made available under a CC-BY-NC-ND 4.0 International license .

\section{Cardiopulmonary Imaging}

\section{Utilization}

cCT $(61 \%)$ and cX-ray (46\%) were the most common cardiopulmonary imaging performed in our cohort; cEcho was carried out in $18 \%$ and LUS in $7 \%$ of patients. The use of imaging modalities was different across regions: cCT was more frequent in Mx and SAm, and cX-ray was significantly more common in CAC. cEcho was almost the same among regions with a small predominance in Mx. LUS was significantly more common in Mx. Brazil had the highest use of both modalities if we analyze based on country. ECG use was limited (24\%) due to the biosafety measures implemented during COVID-19. The lowest use was in SAm (except Brazil). We could also consider an underreporting of ECG due to a lack of digitization (Table 2). cMRI was performed in only one patient in the cohort and was not taken into account for the statistical analysis.

A multivariate analysis of the use of images was carried out considering confounding factors such as: age, sex, hypertension, overweight / obesity, diabetes, renal failure, heart failure, hospital stay, ICU stay, mechanical ventilation and death (Table 3). The calculated adjusted ORs do not appear to add significant variation or

impact.

\section{Findings}

The imaging findings and their regional distribution are shown in Table 4. The most frequent patterns of the cX-ray were peripheral, basal, and ground glass infiltrates with a significant prevalence of abnormalities in Mx. The ground glass appearance of peripheral or subpleural infiltrates on cCT was found in $89 \%$ of cases; the most severe subtypes (infiltrates $>50 \%$ ) were significantly higher in Mx (Figure III). The left ventricular ejection fraction (LVEF) was calculated in all cEcho performed (266 patients) with a mean value of $57 \%$ being almost the same in the three regions.

The right ventricular fractional area (FaRV) was performed in almost $62 \%$ of the cEcho (166 patients) with a mean value of $38 \%$ and no differences between regions. Strain echocardiography was performed only in Mx and SAm. The left ventricular global longitudinal strain (GLSLV) was performed in $21 \%$ of cEcho (57 patients) with a median of -17 ( 7 to -26$)$ and lower in Mx (-13). The right ventricular free wall strain (FWSRV) was achieved in $7 \%$ of cEcho (18 patients) with a median value of - 25 ( -7 to -40$)$; it was also lower in Mx (-15). The trans-mitral/tissue Doppler patterns most frequently were majority normal or impaired relaxation ( $42 \%$ each). The development of abnormal regional wall motility was predominant in CAC. Pericardial effusions was found in $11 \%$ of the patients - the majority in SAm. The most frequent patterns in LUS were the interstitial syndrome (predominant in Mx and CAC) and consolidation (predominant in Mx). Logistic regression showed associations of imaging with comorbidities, complications, and evolution with an estimation of crude OR and their 95\%CI shown in Table 5.

The most frequently finding in ECG was an arrythmia especially in SAm.

\section{Other parameters}

The most prevalent complication was renal failure (20\%) with a significant predominance in Mx and SAm regions. Heart failure developed in 13\% (191 patients) of the cohort with a predominance in $\mathrm{Mx}$ and CAC; left ventricular failure occurred in $46 \%$, right ventricular failure in $20 \%$, and biventricular failure in $34 \%$ of cases. 
medRxiv preprint doi: https://doi.org/10.1101/2022.01.10.22269002; this version posted January 11, 2022. The copyright holder fo8this preprint (which was not certified by peer review) is the author/funder, who has granted medRxiv a license to display the preprint in perpetuity. perpetuity.

Lung thromboembolism was significantly higher in Mx while acute myocardial infarction was predominant in CAC (Table 6).

Modalities of respiratory support had significant differences across regions: Overall, mechanical ventilation (MV) and pronation predominated in Mx ICU patients (85\%-67\% respectively), although the mechanical ventilation duration (hours and days) were higher in SAm. CPAP in mechanical ventilated patients was more common in SAm; ECMO was rarely employed (Table 6)

The overall in-hospital mortality was $28 \%$ (CI:25.2-29.9) and was significantly higher in 65 years with no differences between gender; this is nearly similar to that published in patients from the United Kingdom (19) and slightly higher than that of Iran (20). The higher regional mortality was in Mx (37\%) with no significant differences between CAC and SAm. Rather, if we analyze for each country, then Perú and Argentina had the highest mortality (40\% and 39\% respectively). The ICU mortality was $40 \%$ and was significantly higher in México (52\%). Mortality in patients with mechanical ventilation was 56\% with no differences between regions (Table 6). The risk factors associated with high mortality were HBP, DBT, overweight/obesity, as well as hospitalization location and the requirement of MV.

\section{Discussion}

The SARS-Cov-2 pandemic has had a global influence, but little is known about the impact on LATAM. The respiratory system is dramatically impacted by COVID-19, and this explains the necessary use of cX-ray and cCT overshadowing the use of cEcho and LUS. In this multicenter study, we describe the different modalities of imaging used and their findings in the management of patients affected during the early stages of the COVID-19 disease in LATAM. The three regions had expected as well as unexpected results.

The diagnosis and follow-up of pulmonary involvement was carried out using lung imaging (chest X-ray or cCT). The procedures optimized the technical and human resources available in light of the personnel protection measures. Only in doubtful or complex cases were both techniques used in the same patient (18\%). This could partly explain the difference in the use of these modalities between the three regions. The findings of basal and peripheral infiltrates on chest X-ray and of ground glass infiltrates > $50 \%$ in cCT were correlated with the presence of overweight/obesity, greater occurrence of heart failure, need for mechanical ventilation, and higher mortality (Table 5).

According to SISIAC's recommendations, the use of cEcho during the COVID-19 pandemic in 2020 was limited to patients with hemodynamic instability, new heart failure or ischemic heart disease, complex arrhythmias, or a high suspicion of endocarditis associated with coronavirus. The higher prevalence of heart failure, myocardial infarction, and pulmonary thromboembolism in $\mathrm{Mx}$ and CAC could probably explain the slightly higher use of cEcho in these regions. The findings on this technique showed that the analyzed cohort had a normal mean ejection fraction and diastolic function on admission. The development of a reduced ejection fraction during hospitalization was correlated with the presence of heart failure and ischemic heart disease (Table 5).

Uncertainties about its usefulness and the lack of practice of LUS in patients with pulmonary and cardiac pathology in most LATAM countries contributed to the limit use of this technique except in Mexico and Brazil. Of note, published studies (21) that used LUS in COVID-19 patients were oriented to usefulness and results, and remains unclear what the real rate of LUS use was. Interstitial infiltrates were correlated with higher mortality (Table 5). 
medRxiv preprint doi: https://doi.org/10.1101/2022.01.10.22269002; this version posted January 11, 2022. The copyright holder fo@this preprint (which was not certified by peer review) is the author/funder, who has granted medRxiv a license to display the preprint in It is made available under a CC-BY-NC-ND 4.0 International license .

Regarding regions

We hypothesize that the higher mortality in Mx could be explained by a combination of these findings: a higher prevalence of cX-ray infiltrates; cCT infiltrates $>50 \%$ in more than twothirds of the subjects; high incidence of interstitial syndrome in LUS; highest ICU stay in days; highest proportion of total patients admitted to the ICU with mechanical ventilation and pronation use (more severe ICU patients); and a higher prevalence of pulmonary thromboembolism, heart failure, and renal failure. Furthermore, the high incidence of comorbidities such as obesity, diabetes, and tobacco use suggest a high-risk cohort.

The CAC and SAm regions had fewer numbers of complications; there was less prevalence of abnormal cX-ray findings, and a higher rate of moderate cCT infiltrates (25$50 \%$ ). These regions had a lower proportion of total patients admitted to the ICU with mechanical ventilation and pronation use (less severe ICU patients); these could probably identify a moderate risk cohort. Interestingly, we found that the CAC region had the highest rate of Hypertension and the highest proportion of regional wall motion abnormalities on cEcho while SAm had the highest rate of arrhythmias as well as the highest prevalence of pericardial effusions. We hypothesize that the combination of these factors could probably explain the similar mortality between both regions (24\% and $26 \%$, respectively).

Remarkably, the cardiopulmonary images used, and their findings had a great impact on the diagnosis and prognosis of COVID-19 disease as well as on the mechanical ventilation and pronation necessary to treat it. The addition of comorbidities and complications could explain the different severity rates in these patients.

\section{Strengths}

To the best of our knowledge, this is the first international, multicenter study in LATAM to characterize cardiopulmonary imaging use and their findings in patients hospitalized with COVID-19.

\section{Limitations}

The cohort might not be representative of all COVID-19 hospitalizations in each country. In addition, data were collected during the first pandemic wave and therefore findings may not reflect changes that may have occurred later.

\section{Future Directions}

Subsequently, imaging societies may consider developing risk scoring protocols based on the findings of the images performed.

\section{Conclusion}

Patients hospitalized with COVID-19 had differences in the images used in the three LATAM regions. These could be explained by clinical needs, personnel protection measures and/or hospitalization location. cCT and cX-ray were the most frequently performed modalities, and cEcho was employed in just special clinical situations. Abnormal findings had a great impact on diagnosis and prognosis, on the use of mechanical ventilation, the necessary pronation, and overall mortality. 
medRxiv preprint doi: https://doi.org/10.1101/2022.01.10.22269002; this version posted January 11, 2022. The copyright holder fbӨthis preprint (which was not certified by peer review) is the author/funder, who has granted medRxiv a license to display the preprint in

\section{References:}

1. Peng Z, Xing-Lou Y, Xian-Guang W, et al. A pneumonia outbreak associated with a new coronavirus of probable bat origin. Nature. 2020; 579 (7798):270-273.

2. Nanshan C, Min Z, Xuan D, et al. Epidemiological and clinical characteristics of 99 cases of 2019 novel coronavirus pneumonia in Wuhan, China: a descriptive study. Lancet. 2020;395(10223):507-513

3. Chaolin H, Yeming W, Xingwang L, et al. Clinical features of patients infected with 2019 novel coronavirus in Wuhan, China. Lancet. 2020 Feb 15; 395 (10223):497-506

4. Wu Z, McGoogan JM. Characteristics of and important lessons from the coronavirus disease 2019 (COVID-19) outbreak in China: summary of a report of 72314 cases from the Chinese Center for Disease Control and Prevention. JAMA 2020; 323(13): $1239-1242$.

5. Fang L, Karakiulakis G, Roth M. Are patients with hypertension and diabetes mellitus at increased risk for COVID-19 infection? Lancet Respir Med. 2020 Apr;8(4): e21.

6. Richardson S, Hirsch JS, Narasimhan M, et al. Presenting Characteristics, Comorbidities, and Outcomes Among 5700 Patients Hospitalized With COVID-19 in the New York City Area. JAMA. 2020 May 26;323(20):2052-2059.

7. Wang D, Hu B, Hu C, et al. Clinical characteristics of 138 hospitalized patients with 2019 novel coronavirus-infected pneumonia in Wuhan, China. JAMA. 2020 Feb 7;323(11):1061-1069.

8. Mehraeen E, Seyed Alinaghi SA, Nowroozi A, et al. A systematic review of ECG findings in patients with COVID-19. Indian Heart Journal. Volume 72, Issue 6, November-December 2020, Pages 500-507.

9. Moussa S, Gabriels J, Chang D, et col. Effects of chloroquine, hydroxychloroquine, and azithromycin on QTc of COVID-19 patients. Circulation Arrhythmia and Electrophysiology. 2020 Apr 29; Vol 13(6). 
medRxiv preprint doi: https://doi.org/10.1101/2022.01.10.22269002; this version posted January $11,2022$. The copyright holder fbil this preprint (which was not certified by peer review) is the author/funder, who has granted medRxiv a license to display the preprint in It is made available under a CC-BY-NC-ND 4.0 International license .

10. Ming-Yen N, Elaine Y.P. L, Jin Y, et al. Imaging profile of the covd-19 infection:

radiologic findings and literature review. Radiology Cardiothoracic Imaging 2020;2 (1).

11. Kirkpatrick JN, Mitchell C, Taub C , et al. ASE Statement on Protection of Patients and Echocardiography Service Providers During the 2019 Novel Coronavirus Outbreak: Endorsed by the American College of Cardiology. Journal American Society of Echocardiography 2020 Jun; 33(6): 648-653.

12. Szekely Y, Lichter Y, Taieb P, et al. The Spectrum of Cardiac Manifestations in Coronavirus Disease 2019 (COVID-19) - a Systematic Echocardiographic Study. Circulation. $2020 ; 142: 342-353$.

13. García Fernández MA. La pandemia Covid19 y el uso de la ecocardiografía. RETIC 2020;3(2): 1-4.

14. Li Y, Li H, Zhu S, et al. Prognostic value of right ventricular longitudinal strain in patients with COVID-19. JACC: Cardiovascular Imaging 2020 Nov;13(11):22872299.

15. Hirschaut E, Delgado C. Ecografía Pulmonar: un nuevo abordaje para cardiólogos, RETIC 2018 (1);2:1-7.

16. Poggiali E, Dacrema A, Bastoni D, et al. Can Lung US help critical care clinicians in the early diagnosis of novel coronavirus (COVID-19) pneumonia? Radiology.2020 Jun;295 (3):E6.

17. Feng P, Chuansheng Z, Tianhe Y, et al. Different computed tomography patterns of Coronavirus Disease 2019 (COVID-19) between survivors and non-survivors.

Scientific Reports. 2020 Jul 9;10(1): 11336.

18. Chunqin L, Huaxiang X, Qinglin S, et al. Diagnosis of the Coronavirus disease (COVID-19): rRT-PCR or CT?. European Journal of Radiology. 2020; 126:108961. 
medRxiv preprint doi: https://doi.org/10.1101/2022.01.10.22269002; this version posted January 11, 2022. The copyright holder fb2this preprint (which was not certified by peer review) is the author/funder, who has granted medRxiv a license to display the preprint in It is made available under a CC-BY-NC-ND 4.0 International license .

19. Docherty AB, Harrison EM, Green CA, et al. Features of 20133 UK patients in hospital with covid-19 using the ISARIC WHO Clinical Characterization Protocol: prospective observational cohort study. BMJ 2020 May 22;369:m1985.

20. Jalili M, Payandemehr P, Saghaei A, et al. Characteristics and mortality of hospitalized patients with COVID-19 in Iran: a national retrospective cohort study. Ann Intern Med 2021 Jan;174(1):125-127.

21. Volpicelli G, Gargani L, Perlini S, et al. Lung ultrasound for the early diagnosis of COVID-19 pneumonia: an international multicenter study. Intensive Care Med. 2021 Apr;47(4):444-454.

\section{Figure titles and legends:}

Figure I: RIMAC Registry: Participating regions, countries and institutions (1435 patients)

Figure II: Patients included from February to December 2020 (1435)

Figure III: Image Patterns. A: cTC: infiltrates in ground glass $>50 \%$, crazy paving and alveolar consolidation bilateral; B: cTC: infiltrates in ground glass > 50\% bilateral; C: cTC: infiltrates in ground glass 25 - 50\% and pleural effusion bilateral; D: cTC: infiltrates in ground glass $<25 \%$ and pleural effusion unilateral; E: cX-ray: peripheral, basal and hilar infiltrates, ground glass pattern and consolidation; F: cX-ray: basal, and peripheral infiltrates, and ground glass pattern. 
medRxiv preprint doi: https://doi.org/10.1101/2022.01.10.22269002; this version posted January 11, 2022. The copyright holder fbBthis preprint (which was not certified by peer review) is the author/funder, who has granted medRxiv a license to display the preprint in It is made available under a CC-BY-NC-ND 4.0 International license.

Table 1: Demographic variables and baseline Comorbidities

\begin{tabular}{|c|c|c|c|c|c|}
\hline & $\begin{array}{l}\text { Global } \\
\text { (n: 1435) }\end{array}$ & $\begin{array}{l}\text { Mexico } \\
(\mathbf{M x}) \\
\text { (n: 262) }\end{array}$ & $\begin{array}{c}\text { Central } \\
\text { America and } \\
\text { Caribbean } \\
(\text { CAC) } \\
(n: 428)\end{array}$ & $\begin{array}{c}\text { Southamerica } \\
\text { (SAm) } \\
\text { (n: } 745)\end{array}$ & p-value $*$ \\
\hline Age (years) & $\begin{array}{l}57.95 \\
(\text { SD 16.62) }\end{array}$ & $\begin{array}{l}55.56 \\
\text { (SD 15.41) }\end{array}$ & $\begin{array}{l}59.86 \\
(\text { SD 16.91) }\end{array}$ & $\begin{array}{l}57.69 \\
(\text { SD 16.77) }\end{array}$ & $\begin{array}{l}0.002 \\
0.003 \\
0.094 \\
0.222\end{array}$ \\
\hline Male gender & $64.46 \%(925)$ & $58.40 \%(153)$ & $70.33 \%(301)$ & $63.22 \%(471)$ & $\begin{array}{l}0.004 \\
0.001 \\
0.014 \\
0.166\end{array}$ \\
\hline
\end{tabular}

\section{Baseline Comorbilities}

\begin{tabular}{|c|c|c|c|c|c|}
\hline $\begin{array}{l}\text { Overweight/obesity } \\
(\mathrm{BMI} \geq 25)\end{array}$ & $61.25 \%(879)$ & $80.92 \%$ (212) & $64.95 \%$ (278) & $52.21 \%(389)$ & $\begin{array}{l}0.001 \\
0.001 \\
0.001 \\
0.001\end{array}$ \\
\hline $\begin{array}{l}\text { Overweight } \\
\text { (BMI } 25 \text { to 29) }\end{array}$ & $35.75 \%(513)$ & $38.55 \%(101)$ & 43.93\% (188) & $30.07 \%$ (224) & $\begin{array}{l}0.001 \\
0.165 \\
0.001 \\
0.012\end{array}$ \\
\hline $\begin{array}{l}\text { Obesity } \\
(\mathrm{BMI} \geq 30)\end{array}$ & $25.51 \%(366)$ & $42.37 \%(111)$ & $21.03 \%(90)$ & $22.15 \%(165)$ & $\begin{array}{l}0.001 \\
0.001 \\
0.654 \\
0.001\end{array}$ \\
\hline HBP & $45.37 \%(651)$ & $36.26 \%(95)$ & $60.28 \%$ (258) & $40.00 \%(298)$ & $\begin{array}{l}0.001 \\
0.001 \\
0.001 \\
0.286\end{array}$ \\
\hline DBT & $26.83 \%(385)$ & $34.35 \%(90)$ & $33.64 \%$ (144) & $20.27 \%(151)$ & $\begin{array}{l}0.001 \\
0.849 \\
0.001 \\
0.001\end{array}$ \\
\hline Ex tobacco use & $14.15 \%(203)$ & $6.87 \%(18)$ & $19.63 \%(84)$ & $13.56 \%(101)$ & $\begin{array}{l}0.001 \\
0.001 \\
0.006 \\
0.004\end{array}$ \\
\hline Active tobacco use & $8.43 \%(121)$ & $13.74 \%(36)$ & $7.94 \%(34)$ & $6.85 \%(51)$ & $\begin{array}{l}0.002 \\
0.014\end{array}$ \\
\hline
\end{tabular}


medRxiv preprint doi: https://doi.org/10.1101/2022.01.10.22269002; this version posted January 11, 2022. The copyright holder fbłthis preprint (which was not certified by peer review) is the author/funder, who has granted medRxiv a license to display the preprint in It is made available under a CC-BY-NC-ND 4.0 International license .

\begin{tabular}{|c|c|c|c|c|c|}
\hline & & & & & $\begin{array}{l}0.485 \\
0.001\end{array}$ \\
\hline Ischemic heart disease & $6.76 \%(97)$ & $4.96 \%(13)$ & $9.58 \%(41)$ & $5.77 \%(43)$ & $\begin{array}{l}0.019 \\
\\
0.028 \\
0.015 \\
0.623\end{array}$ \\
\hline COPD & $6.62 \%(95)$ & $2.67 \%(7)$ & $2.10 \%(9)$ & $10.60 \%(79)$ & $\begin{array}{l}0.001 \\
0.630 \\
0.001 \\
0.001\end{array}$ \\
\hline Renal failure & $4.32 \%(62)$ & $1.91 \%(5)$ & $2.80 \%(12)$ & $6.04 \%(45)$ & $\begin{array}{l}0.003 \\
0.462 \\
0.013 \\
0.008\end{array}$ \\
\hline Myocardiopathy & $4.74 \%(68)$ & $0.00 \%(0)$ & $9.11 \%(39)$ & $3.89 \%(29)$ & $\begin{array}{l}0.001 \\
0.001 \\
0.001 \\
0.001\end{array}$ \\
\hline Valvular heart disease & $1.74 \%(25)$ & $2.29 \%(6)$ & $2.57 \%(11)$ & $1.07 \%(8)$ & $\begin{array}{l}0.128 \\
\text { N/A }\end{array}$ \\
\hline HIV & $0.42 \%(6)$ & $0.38 \%(1)$ & $0.00 \%(0)$ & $0.67 \%(5)$ & $\begin{array}{l}0.229 \\
\text { N/A }\end{array}$ \\
\hline \multicolumn{6}{|c|}{$\begin{array}{l}\text { *Each cell contains four p-values. } \\
\text { The first } p \text {-value corresponds to chi-squared test (for categorical variables) or one-way ANOVA test } \\
\text { (for numerical variables). Only a } p \leq 0.016 \text { was considered statistically significance. } \\
\text { The second, third and fourth corresponds to multiple comparisons between groups: Mx and CAC, CAC and } \\
\text { SAm, SAm and Mx, respectively. We used multiple chi-squared tests and ANOVA with Bonferroni } \\
\text { correction. }\end{array}$} \\
\hline
\end{tabular}

HBP: Hight Blood Pressure; DBT: Diabetes; COPD: Chronic obstructive pulmonary disease; HIV: Human immunodeficiency virus 
medRxiv preprint doi: https://doi.org/10.1101/2022.01.10.22269002; this version posted January $11,2022$. The copyright holder fb5this preprint (which was not certified by peer review) is the author/funder, who has granted medRxiv a license to display the preprint in It is made available under a CC-BY-NC-ND 4.0 International license .

Table 2: Image modalities used

\begin{tabular}{|c|c|c|c|c|c|}
\hline & $\begin{array}{l}\text { Global } \\
\text { (n: 1435) }\end{array}$ & $\begin{array}{c}\text { Mexico }(M x) \\
\text { (n: 262) }\end{array}$ & $\begin{array}{l}\text { Central } \\
\text { America and } \\
\text { Caribbean } \\
\text { (CAC) } \\
\text { (n: 428) }\end{array}$ & $\begin{array}{l}\text { Southamerica } \\
\text { (Sam) } \\
\text { (n: } 745)\end{array}$ & p-value* \\
\hline $\begin{array}{l}\text { Chest computed } \\
\text { tomography } \\
\text { ( cCT ) }\end{array}$ & $61.53 \%(883)$ & $69.08 \%(181)$ & $32.24 \%(138)$ & $75.70 \%$ (564) & $\begin{array}{l}0.001 \\
0.001 \\
0.001 \\
0.036\end{array}$ \\
\hline $\begin{array}{l}\text { Chest R-ray } \\
\text { ( cX-ray) }\end{array}$ & $45.99 \%(660)$ & $38.55 \%(101)$ & $91.12 \%(390)$ & $22.68 \%(169)$ & $\begin{array}{l}0.001 \\
0.001 \\
0.001 \\
0.001\end{array}$ \\
\hline $\begin{array}{l}\text { Echocardiogram } \\
\text { ( cEcho ) }\end{array}$ & $18.54 \%(266)$ & $24.43 \%(64)$ & $18.93 \%(81)$ & $16.24 \%(121)$ & $\begin{array}{l}0.013 \\
0.085 \\
0.241 \\
0.003\end{array}$ \\
\hline $\begin{array}{l}\text { Lung ultrasound } \\
\text { ( LUS ) }\end{array}$ & $7.25 \%(104)$ & $22.14 \%(58)$ & $0.23 \%(1)$ & $6.04 \%(45)$ & $\begin{array}{l}0.001 \\
0.001 \\
0.001 \\
0.001\end{array}$ \\
\hline $\begin{array}{l}\text { Electrocardiogram } \\
\text { ( ECG ) }\end{array}$ & $24.32 \%(349)$ & $41.22 \%(108)$ & $37.62 \%(161)$ & $10.74 \%(80)$ & $\begin{array}{l}0.001 \\
0.346 \\
0.001 \\
0.001\end{array}$ \\
\hline \multicolumn{6}{|c|}{$\begin{array}{l}\text { The first p'value corresponds to chi-squared test (for categorical variables) or one-way ANOVA test } \\
\text { (for numerical variables). Only a } p \leq 0.016 \text { was considered statistically significance. }\end{array}$} \\
\hline $\begin{array}{l}\text { The second, third an } \\
\text { SAm, SAm and Mx, }\end{array}$ & th correspond & ultiple comp & $\mathrm{s}$ between gro & Mx and CAC, & $\begin{array}{l}\text { and } \\
\text { rection. }\end{array}$ \\
\hline
\end{tabular}


medRxiv preprint doi: https://doi.org/10.1101/2022.01.10.22269002; this version posted January 11, 2022. The copyright holder fb6this preprint (which was not certified by peer review) is the author/funder, who has granted medRxiv a license to display the preprint in It is made available under a CC-BY-NC-ND 4.0 International license .

Table 3: Image modalities used and confounders: multivariate analysis

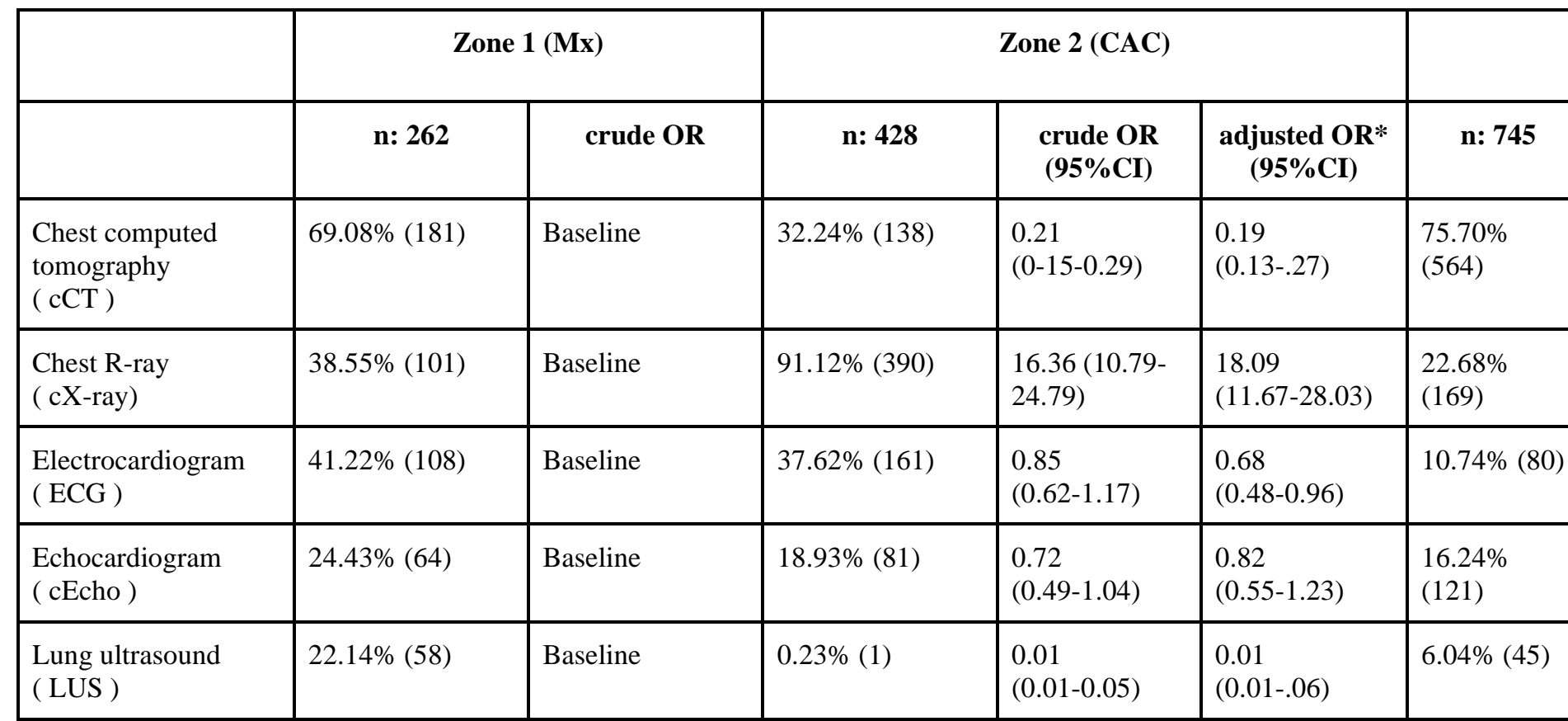

* Confounders: Age, Sex, hypertension, overweight/obesity, diabetes, renal failure, cardiac failure, hospital stay, ICU, MV, death 
medRxiv preprint doi: https://doi.org/10.1101/2022.01.10.22269002; this version posted January $11,2022$. The copyright holder fb/this preprint (which was not certified by peer review) is the author/funder, who has granted medRxiv a license to display the preprint in It is made available under a CC-BY-NC-ND 4.0 International license.

Table 4: Image Patterns Global and Regions

\begin{tabular}{|c|c|c|c|c|c|}
\hline & $\begin{array}{l}\text { Global } \\
\text { (n: 1435) }\end{array}$ & $\begin{array}{l}\text { Mexico } \\
\text { (Mx) } \\
(\mathbf{n :} 262)\end{array}$ & $\begin{array}{l}\text { Central } \\
\text { America and } \\
\text { Caribbean } \\
\text { (CAC) } \\
(\text { n: 428) }\end{array}$ & $\begin{array}{c}\begin{array}{c}\text { Southamerica } \\
\text { (SAm) }\end{array} \\
\text { (n: 745) }\end{array}$ & $\begin{array}{c}\text { p- } \\
\text { value* }\end{array}$ \\
\hline $\begin{array}{l}\text { CHEST COMPUTED } \\
\text { TOMOGRAPHY } \\
\text { ( cCT ) }\end{array}$ & $61.53 \%(\mathbf{8 8 3})$ & $69.08 \%(\mathbf{1 8 1})$ & $32.24 \%(\mathbf{1 3 8})$ & $75.70 \%(\mathbf{5 6 4})$ & $\begin{array}{l}0.001 \\
\\
0.001 \\
0.001 \\
0.036\end{array}$ \\
\hline Infiltrates in ground glass & $\begin{array}{l}89.35 \% \\
(789 / 883)\end{array}$ & $99.45 \%(180)$ & $87.68 \%(121)$ & $86.52 \%(488)$ & $\begin{array}{l}0.001 \\
0.001 \\
0.719 \\
0.001\end{array}$ \\
\hline $\begin{array}{c}\text { Infiltrates, } \% \\
\\
25-50 \% \\
<25 \% \\
>50 \%\end{array}$ & $\begin{array}{l}32.95 \% \\
(260 / 789) \\
21.29 \% \\
(168 / 789) \\
45.75 \% \\
(361 / 789)\end{array}$ & $\begin{array}{l}18.33 \%(33) \\
13.33 \%(24) \\
68.33 \%(123)\end{array}$ & $\begin{array}{l}41.32 \%(50) \\
33.06 \%(40) \\
25.62 \%(31)\end{array}$ & $\begin{array}{l}36.27 \%(177) \\
21.31 \%(104) \\
42.42 \%(207)\end{array}$ & $\begin{array}{l}0.001 \\
\text { N/A }\end{array}$ \\
\hline Crazy Paving & $\begin{array}{l}30.01 \% \\
(618 / 883)\end{array}$ & $20.99 \%(38)$ & $45.65 \%(63)$ & $29.08 \%(164)$ & $\begin{array}{l}0.001 \\
\\
0.001 \\
0.001 \\
0.033\end{array}$ \\
\hline Alveolar Consolidation & $\begin{array}{l}36.58 \% \\
(323 / 883)\end{array}$ & $35.36 \%(64)$ & $42.75 \%(59)$ & $35.46 \%(200)$ & $\begin{array}{l}0.261 \\
\text { N/A }\end{array}$ \\
\hline Pleural Effusion & $10.76 \%(95 / 883)$ & $12.71 \%(23)$ & $18.84 \%(26)$ & $8.16 \%(46)$ & $\begin{array}{l}0.001 \\
\\
0.132 \\
0.001 \\
0.066\end{array}$ \\
\hline $\begin{array}{l}\text { CHEST R-RAY } \\
\text { ( cX-ray ) }\end{array}$ & $45.99 \%(\mathbf{6 6 0})$ & $38.55 \%(\mathbf{1 0 1})$ & $91.12 \%(\mathbf{3 9 0})$ & $22.68 \%(\mathbf{1 6 9})$ & $\begin{array}{l}0.001 \\
0.001 \\
0.001 \\
0.001\end{array}$ \\
\hline Basal Infiltrates & $\begin{array}{l}51.97 \% \\
(343 / 660)\end{array}$ & $83.17 \%(84)$ & $41.28 \%(161)$ & $57.99 \%(98)$ & $\begin{array}{l}0.001 \\
0.001 \\
0.001 \\
0.001\end{array}$ \\
\hline Peripheral Infiltrates & $\begin{array}{l}63.33 \% \\
(418 / 660)\end{array}$ & $89.11 \%(90)$ & $58.97 \%(230)$ & $57.99 \%(98)$ & $\begin{array}{l}0.001 \\
0.001 \\
0.828 \\
0.001\end{array}$ \\
\hline
\end{tabular}


medRxiv preprint doi: https://doi.org/10.1101/2022.01.10.22269002; this version posted January 11, 2022. The copyright holder fb8this preprint (which was not certified by peer review) is the author/funder, who has granted medRxiv a license to display the preprint in

It is made available under a CC-BY-NC-ND 4.0 International license

\begin{tabular}{|c|c|c|c|c|c|}
\hline Hilar Infiltrates & $\begin{array}{l}39.24 \% \\
(259 / 660)\end{array}$ & $54.46 \%(55)$ & $44.87 \%(175)$ & $17.16 \%(29)$ & $\begin{array}{l}0.001 \\
0.085 \\
0.001 \\
0.001\end{array}$ \\
\hline Ground Glass pattern & $\begin{array}{l}45.00 \% \\
(297 / 660)\end{array}$ & $74.26 \%(75)$ & $43.59 \%(170)$ & $30.77 \%(52)$ & $\begin{array}{l}0.001 \\
0.001 \\
0.004 \\
0.004\end{array}$ \\
\hline Consolidation & $\begin{array}{l}25.15 \% \\
(166 / 660)\end{array}$ & $57.43 \%(58)$ & $19.23 \%(75)$ & $19.53 \%(33)$ & $\begin{array}{l}0.001 \\
0.001 \\
0.935 \\
0.001\end{array}$ \\
\hline $\begin{array}{l}\text { ECHOCARDIOGRA } \\
\text { M } \\
\text { ( cEcho ) }\end{array}$ & $18.54 \%(\mathbf{2 6 6})$ & $24.43 \%(\mathbf{6 4})$ & $18.93 \%(\mathbf{8 1})$ & $16.24 \%(\mathbf{1 2 1})$ & $\begin{array}{l}0.013 \\
0.085 \\
0.241 \\
0.003\end{array}$ \\
\hline $\begin{array}{l}\text { Left ventricular ejection } \\
\text { fraction } \\
\text { (LVEF) } \\
(\mathrm{n}: 266)\end{array}$ & 56.89 (SD 11.89) & $57.40($ SD 9.78) & $\begin{array}{l}54.48(\mathrm{SD} \\
13.97)\end{array}$ & $\begin{array}{l}58.23(\mathrm{SD} \\
11.22)\end{array}$ & $\begin{array}{l}0.008 \\
0.421 \\
0.083 \\
1.000\end{array}$ \\
\hline $\begin{array}{l}\text { Right ventricular } \\
\text { fractional area } \\
\text { (FaRV) } \\
\text { (n: 166) }\end{array}$ & $38.17(\mathrm{SD} 10.61)$ & 34.71 (SD 7.87) & $30.33(\mathrm{SD} 6.80)$ & $\begin{array}{l}40.20(\mathrm{SD} \\
11.41)\end{array}$ & $\begin{array}{l}0.002 \\
1.000 \\
0.311 \\
0.004\end{array}$ \\
\hline $\begin{array}{l}\text { Left ventricular global } \\
\text { longitudinal strain } \\
\text { (GLS LV) } \\
\text { (n: } 57)\end{array}$ & $-17.31(\mathrm{SD} 5.18)$ & $-13(\mathrm{SD} 0)$ & $-11.2(\mathrm{SD} 3.65)$ & $\begin{array}{l}-18.74(\mathrm{SD} \\
4.47)\end{array}$ & $\begin{array}{l}0.001 \\
1.000 \\
0.001 \\
0.591\end{array}$ \\
\hline $\begin{array}{l}\text { Right ventricular free } \\
\text { wall strain } \\
\text { (FWSRV) } \\
\text { (n: 18) }\end{array}$ & $-24.85(\mathrm{SD} 6.85)$ & $-15(\mathrm{SD} 0)$ & N/A & $\begin{array}{l}-25.42(\mathrm{SD} \\
6.60)\end{array}$ & 0.144 \\
\hline $\begin{array}{l}\text { Trans-mitral Pattern } \\
\text { LV impaired relaxation } \\
\text { Atrial Fibrillation } \\
\text { Normal } \\
\text { Restrictive pattern } \\
\text { Seudonormal pattern }\end{array}$ & $\begin{array}{l}41.73 \% \\
(111 / 266) \\
7.89 \%(21 / 266) \\
42.48 \% \\
(113 / 266) \\
2.63 \%(7 / 266) \\
5.26 \%(14 / 266)\end{array}$ & $\begin{array}{l}68.75 \%(44) \\
3.12 \%(2) \\
26.56 \%(17) \\
0.00 \%(0) \\
1.56 \%(1)\end{array}$ & $\begin{array}{l}30.86 \%(25) \\
4.94 \%(4) \\
51.85 \%(42) \\
4.94 \%(4) \\
7.41 \%(6)\end{array}$ & $\begin{array}{l}34.71 \%(42) \\
12.40 \%(15) \\
44.63 \%(54) \\
2.48 \%(3) \\
5.79 \%(7)\end{array}$ & $\begin{array}{l}0.001 \\
\text { N/A }\end{array}$ \\
\hline Abnormal motility & $15.79 \%(42 / 266)$ & $9.38 \%(6)$ & $25.93 \%(21)$ & $12.40 \%(15)$ & $\begin{array}{l}0.010 \\
0.011 \\
0.014 \\
0.538\end{array}$ \\
\hline
\end{tabular}


medRxiv preprint doi: https://doi.org/10.1101/2022.01.10.22269002; this version posted January 11, 2022. The copyright holder fbßthis preprint (which was not certified by peer review) is the author/funder, who has granted medRxiv a license to display the preprint in

\begin{tabular}{|c|c|c|c|c|c|}
\hline Pericardial Effusion & $10.90 \%(29)$ & $3.12 \%(2)$ & $4.94 \%(4)$ & $19.01 \%(23)$ & $\begin{array}{l}0.001 \\
0.586 \\
0.004 \\
0.003\end{array}$ \\
\hline $\begin{array}{l}\text { LUNG } \\
\text { ULTRASOUND } \\
\text { ( LUS ) }\end{array}$ & $7.25 \%(\mathbf{1 0 4})$ & $22.14 \%(\mathbf{5 8})$ & $0.23 \%(\mathbf{1})$ & $6.04 \%(45)$ & $\begin{array}{l}0.001 \\
0.001 \\
0.001 \\
0.001\end{array}$ \\
\hline Interstitial Syndrome & $55.77 \%(58 / 104)$ & $96.55 \%(56)$ & $100.00 \%(1)$ & $2.22 \%(1)$ & $\begin{array}{l}0.001 \\
0.850 \\
0.001 \\
0.001\end{array}$ \\
\hline Consolidation & $\begin{array}{l}25.15 \% \\
(166 / 104)\end{array}$ & $47.83 \%(11)$ & $0.00 \%(0)$ & $0.00 \%(0)$ & $\begin{array}{l}0.426 \\
\text { N/A }\end{array}$ \\
\hline Pleural Effusion & $9.62 \%(10 / 104)$ & $5.17 \%(3)$ & $0.00 \%(0)$ & $15.56 \%(7)$ & $\begin{array}{l}0.197 \\
\text { N/A }\end{array}$ \\
\hline \multicolumn{6}{|c|}{$\begin{array}{l}\text { *Each cell contains four p-values. } \\
\text { The first p'value corresponds to chi-squared test (for categorical variables) or one-way ANOVA test (for } \\
\text { numerical variables). Only a } p \leq 0.016 \text { was considered statistically significance. }\end{array}$} \\
\hline \multicolumn{6}{|c|}{$\begin{array}{l}\text { The second, third and fourth corresponds to multiple comparisons between groups: Mx and CAC, CAC and SAm, } \\
\text { SAm and Mx, respectively. We used multiple chi-squared tests and ANOVA with Bonferroni correction. }\end{array}$} \\
\hline
\end{tabular}


medRxiv preprint doi: https://doi.org/10.1101/2022.01.10.22269002; this version posted January 11, 2022. The copyright holder 10 this preprint (which was not certified by peer review) is the author/funder, who has granted medRxiv a license to display the preprint in It is made available under a CC-BY-NC-ND 4.0 International license.

Table 5: Modalities imaging logistic regression associated with comorbidities, complications and evolution

\begin{tabular}{|c|c|c|c|c|c|}
\hline & \multicolumn{2}{|c|}{$\begin{array}{l}\text { Chest R-ray } \\
\text { (cX-ray ) }\end{array}$} & \multirow{2}{*}{$\begin{array}{c}\begin{array}{c}\text { Chest } \\
\text { computed }\end{array} \\
\text { tomography } \\
\text { ( cCT ) } \\
\text { (n: } 883) \\
\begin{array}{c}\text { Infiltrates > } \\
50 \% \\
\text { (n: } 361)\end{array}\end{array}$} & \multirow{2}{*}{$\begin{array}{c}\begin{array}{c}\text { Echocardiogra } \\
\text { m }\end{array} \\
\text { ( cEcho ) } \\
\text { (n: 266) } \\
\begin{array}{c}\text { Abnormal } \\
\text { LVEF } \\
\text { (n: 62) }\end{array}\end{array}$} & \multirow{2}{*}{$\begin{array}{c}\begin{array}{c}\text { Lung } \\
\text { Ultrasound } \\
\text { ( LUS ) }\end{array} \\
\\
\text { (n: 104) } \\
\begin{array}{c}\text { Interstitial } \\
\text { Syndrome } \\
\text { (n: 58) }\end{array}\end{array}$} \\
\hline & $\begin{array}{c}\text { Basal } \\
\text { Infiltrates } \\
\text { (n: 343) }\end{array}$ & $\begin{array}{c}\text { Peripheral } \\
\text { Infiltrates } \\
\text { (n: 418) }\end{array}$ & & & \\
\hline $\begin{array}{l}\text { Overweight / } \\
\text { Obesity }\end{array}$ & $\begin{array}{l}1.75(1.27- \\
2.41)\end{array}$ & $\begin{array}{l}2.93(2.10- \\
4.08)\end{array}$ & $\begin{array}{l}1.84(1.36- \\
2.49)\end{array}$ & & \\
\hline Heart failure & $\begin{array}{l}2.06(1.35- \\
3.14)\end{array}$ & & $\begin{array}{l}2.75(1.73- \\
4.36)\end{array}$ & $\begin{array}{l}7.26(3.73- \\
14.16)\end{array}$ & \\
\hline $\begin{array}{l}\text { Ischemic heart } \\
\text { disease }\end{array}$ & & $\begin{array}{l}0.43(0.24- \\
0.75)\end{array}$ & & $\begin{array}{l}15.64(6.77- \\
36.14)\end{array}$ & $\begin{array}{l}0.16(0.03- \\
0.84)\end{array}$ \\
\hline $\begin{array}{l}\text { Mechanical } \\
\text { ventilation }\end{array}$ & $\begin{array}{l}2.84(2.05- \\
3.94)\end{array}$ & $\begin{array}{l}1.66(1.19- \\
2.32)\end{array}$ & $\begin{array}{l}4.99(3.66- \\
6.81)\end{array}$ & & \\
\hline Mortality & $\begin{array}{l}2.84(1.99- \\
4.06)\end{array}$ & $\begin{array}{l}1.87(1.30- \\
2.70)\end{array}$ & $\begin{array}{l}3.68(2.63- \\
5.15)\end{array}$ & & $\begin{array}{l}2.64(1.14- \\
6.09)\end{array}$ \\
\hline \multicolumn{6}{|c|}{ Logistic regression was used for estimation of crude OR and their 95\%CI. } \\
\hline
\end{tabular}

LVEF: left ventricular ejection fraction; OR: Odds ratio; CI: confidence interval 
medRxiv preprint doi: https://doi.org/10.1101/2022.01.10.22269002; this version posted January 11, 2022. The copyright holder 8 llthis preprint (which was not certified by peer review) is the author/funder, who has granted medRxiv a license to display the preprint in It is made available under a CC-BY-NC-ND 4.0 International license.

Table 6: Complications and Evolution

\begin{tabular}{|c|c|c|c|c|c|}
\hline & $\begin{array}{l}\text { Global } \\
\text { (n: 1435) }\end{array}$ & $\begin{array}{l}\text { Mexico } \\
(\mathrm{Mx}) \\
(\mathrm{n}: 262)\end{array}$ & $\begin{array}{l}\text { Central America } \\
\text { and Caribbean } \\
\text { (CAC) } \\
\text { (n: 428) }\end{array}$ & $\begin{array}{c}\text { Southamerica } \\
\text { (SAm) } \\
\text { (n: 745) }\end{array}$ & p-value* \\
\hline \multicolumn{6}{|l|}{ Complications } \\
\hline Renal Failure & $20.14 \%(289$ & $22.52 \%(59)$ & $13.32 \%(57)$ & $23.22 \%(173)$ & $\begin{array}{l}0.001 \\
0.002 \\
0.001 \\
0.816\end{array}$ \\
\hline $\begin{array}{l}\text { Heart Failure } \\
\qquad \begin{array}{l}\text { RV } \\
\text { LV } \\
\text { RV + LV }\end{array}\end{array}$ & $\begin{array}{l}13.13 \%(191) \\
20.41 \%(39 / 191) \\
45.54 \%(87 / 191) \\
34.05 \%(65 / 191)\end{array}$ & $16.79 \%(44)$ & $19.86 \%(85)$ & $8.32 \%(62)$ & $\begin{array}{l}0.001 \\
0.316 \\
0.001 \\
0.001\end{array}$ \\
\hline Cardiac arrest & $4.81 \%(69)$ & $0.76 \%(2)$ & $9.58 \%(41)$ & $3.49 \%(26)$ & $\begin{array}{l}0.001 \\
0.001 \\
0.001 \\
0.021\end{array}$ \\
\hline $\begin{array}{l}\text { Myocardial } \\
\text { Infarction }\end{array}$ & $4.04 \%(58)$ & $2.29 \%(6)$ & $7.94 \%(34)$ & $2.42 \%(18)$ & $\begin{array}{l}0.001 \\
0.002 \\
0.001 \\
0.908\end{array}$ \\
\hline Myocarditis & $3.41 \%(49)$ & $3.44 \%(9)$ & $7.71 \%(33)$ & $0.94 \%(7)$ & $\begin{array}{l}0.001 \\
0.023 \\
0.001 \\
0.005\end{array}$ \\
\hline $\begin{array}{l}\text { Lung } \\
\text { Thromboembolism }\end{array}$ & $3.34 \%(48)$ & $10.69 \%(28)$ & $1.40 \%(6)$ & $1.88 \%(14)$ & $\begin{array}{l}0.001 \\
0.001 \\
0.543 \\
0.001\end{array}$ \\
\hline $\begin{array}{l}\text { Deep Venous } \\
\text { Thrombosis }\end{array}$ & $0.56 \%(8)$ & $0.38 \%(1)$ & $0.70 \%(3)$ & $0.54 \%(4)$ & $\begin{array}{l}0.856 \\
\text { N/A }\end{array}$ \\
\hline Takotsubo & $0.21 \%(3)$ & $0.38 \%$ & $0.23 \%$ & $0.13 \%$ & $\begin{array}{l}0.746 \\
\text { N/A }\end{array}$ \\
\hline \multicolumn{6}{|l|}{ Evolution } \\
\hline WARD admission & $49.34 \%$ (708) & $61.07 \%(160)$ & $47.90(205)$ & $46.04 \%(343)$ & 0.001 \\
\hline
\end{tabular}


medRxiv preprint doi: https://doi.org/10.1101/2022.01.10.22269002; this version posted January 11, 2022. The copyright holder 12 this preprint (which was not certified by peer review) is the author/funder, who has granted medRxiv a license to display the preprint in It is made available under a CC-BY-NC-ND 4.0 International license

\begin{tabular}{|c|c|c|c|c|c|}
\hline & the & t a d & - & & $\begin{array}{l}0.001 \\
0.539 \\
0-001\end{array}$ \\
\hline ICU admission & $50.66 \%(727)$ & $38.93 \%(102)$ & $52.10 \%(223)$ & $53.96 \%(402)$ & $\begin{array}{l}0.001 \\
\\
0.001 \\
0.539 \\
0.001\end{array}$ \\
\hline $\begin{array}{l}\text { ICU during } \\
\text { hospitaization }\end{array}$ & $58.26 \%(836)$ & $60.69 \%(159)$ & $57.48 \%(246)$ & $57.85 \%(431)$ & $\begin{array}{l}0.672 \\
\text { N/A }\end{array}$ \\
\hline Hospitalization Days & 17.49 (SD 17.24) & $16.01(\mathrm{SD} 261)$ & $15.39(\mathrm{SD} 16.04)$ & $19.21(\mathrm{SD} 19.02)$ & $\begin{array}{l}0.001 \\
1.000 \\
0.001 \\
0.028\end{array}$ \\
\hline ICU Days & $13.56(\mathrm{SD} 14.2)$ & $13.35(\mathrm{SD} 12.68)$ & $7.94(\mathrm{SD} 8.36)$ & $16.73(\mathrm{SD} 16.09)$ & $\begin{array}{l}0.001 \\
0.003 \\
0.001 \\
0.079\end{array}$ \\
\hline $\begin{array}{l}\text { Mechanical } \\
\text { ventilation / total } \\
\text { patients }\end{array}$ & $37.91 \%(544)$ & $51.53 \%(135)$ & $29.91 \%(128)$ & $37.72 \%(281)$ & $\begin{array}{l}0.001 \\
0.001 \\
0.007 \\
0.001\end{array}$ \\
\hline $\begin{array}{l}\text { Mechanical } \\
\text { ventilation / ICU } \\
\text { patients }\end{array}$ & $65.07 \%(544 / 836)$ & $84.91 \%(135 / 159)$ & $52.03 \%(128 / 246)$ & $65.20 \%(281 / 431)$ & $\begin{array}{l}0.001 \\
\\
0.001 \\
0.001 \\
0.001\end{array}$ \\
\hline $\begin{array}{l}\text { Mechanical } \\
\text { ventilation duration } \\
\text { (hours) }\end{array}$ & $\begin{array}{l}356.61 \\
(\text { SD 298.12) }\end{array}$ & $\begin{array}{l}308.26 \\
(\text { SD 271.15) }\end{array}$ & $\begin{array}{l}241.89 \\
(\text { SD 198.75) }\end{array}$ & $\begin{array}{l}432.11 \\
\text { (SD 326.17) }\end{array}$ & $\begin{array}{l}0.001 \\
\\
0.185 \\
0.001 \\
0.001\end{array}$ \\
\hline $\begin{array}{l}\text { Mechanical } \\
\text { ventilation duration } \\
\text { (days) }\end{array}$ & $14.85(\mathrm{SD} 12.42)$ & $12.84(\mathrm{SD} 11.29)$ & $10.07(\mathrm{SD} 8.28)$ & $18.01(\mathrm{SD} 13.59)$ & $\begin{array}{l}0.001 \\
\\
0.185 \\
0.001 \\
0.001\end{array}$ \\
\hline Prone / total patients & $22.37 \%(321)$ & $41.98 \%(110)$ & $7.24 \%(31)$ & $24.16 \%(180)$ & $\begin{array}{l}0.001 \\
0.001 \\
0.007 \\
0.001\end{array}$ \\
\hline Prone / ICU patients & $37.80 \%(316 / 836)$ & $67.30 \%(107 / 159)$ & $11.79 \%(29 / 246)$ & $41.76 \%(180 / 431)$ & $\begin{array}{l}0.001 \\
0.001 \\
0.001 \\
0.001\end{array}$ \\
\hline $\begin{array}{l}\text { Prone / Mechanical } \\
\text { ventilation }\end{array}$ & $50.18 \%(273 / 544)$ & $72.59 \%(98 / 135)$ & $18.75 \%(24 / 128)$ & $53.74 \%(151 / 281)$ & 0.001 \\
\hline
\end{tabular}


medRxiv preprint doi: https://doi.org/10.1101/2022.01.10.22269002; this version posted January 11, 2022. The copyright holder 8 Bthis preprint (which was not certified by peer review) is the author/funder, who has granted medRxiv a license to display the preprint in

It is made available under a CC-BY-NC-ND 4.0 International license

\begin{tabular}{|c|c|c|c|c|c|}
\hline & & & & & $\begin{array}{l}0.001 \\
0.001 \\
0.001\end{array}$ \\
\hline $\begin{array}{l}\text { Prone duration } \\
\text { (hours) }\end{array}$ & $\begin{array}{l}137.09 \\
\text { (SD 94.74) }\end{array}$ & $\begin{array}{l}141.6 \\
\text { (SD 91.19) }\end{array}$ & $\begin{array}{l}61.93 \\
(\text { SD } 56.71)\end{array}$ & $\begin{array}{l}147.28 \\
(\mathrm{SD} 96.68)\end{array}$ & $\begin{array}{l}0.004 \\
0.001 \\
0.001 \\
1.000\end{array}$ \\
\hline CPAP / total patients & $13.17 \%(189)$ & $12.21 \%(32)$ & $10.28 \%(44)$ & $15.17 \%(113)$ & $\begin{array}{l}0.051 \\
\text { N/A }\end{array}$ \\
\hline $\begin{array}{l}\text { CPAP / Mechanical } \\
\text { ventilation }\end{array}$ & $17.83 \%(97 / 544)$ & $9.63 \%(13 / 135)$ & $13.28 \%(17 / 128)$ & $23.84 \%(67 / 281)$ & 0.001 \\
\hline $\begin{array}{l}\text { CPAP duration } \\
\text { (hours) }\end{array}$ & $\begin{array}{l}120.42 \\
(\mathrm{SD} 120.63)\end{array}$ & $\begin{array}{l}98.25 \\
\text { (SD 93.32) }\end{array}$ & $\begin{array}{l}83.45 \\
\text { (SD 96.48) }\end{array}$ & $\begin{array}{l}141.10 \\
(\mathrm{SD} 131.65)\end{array}$ & $\begin{array}{l}0.012 \\
1.000 \\
0.020 \\
0.218\end{array}$ \\
\hline Nasal cannula & $49.69 \%(713)$ & $66.41 \%(174)$ & $49.07 \%(210)$ & $44.16 \%(329)$ & $\begin{array}{l}0.001 \\
0.001 \\
0.105 \\
0.001\end{array}$ \\
\hline $\begin{array}{l}\text { Nasal cannula } \\
\text { duration (hours) }\end{array}$ & $\begin{array}{l}150.90 \\
(\mathrm{SD} 149.49)\end{array}$ & $\begin{array}{l}214.20 \\
(\text { SD } 161.48)\end{array}$ & $\begin{array}{l}80.11 \\
\text { (SD 76.38) }\end{array}$ & $\begin{array}{l}162.60 \\
(\mathrm{SD} 159.90)\end{array}$ & $\begin{array}{l}0.001 \\
0.001 \\
0.001 \\
0.001\end{array}$ \\
\hline ECMO & $0.56 \%(8)$ & $0.38 \%(1)$ & $0.00 \%(0)$ & $0.94 \%(7)$ & $\begin{array}{l}0.105 \\
\text { N/A }\end{array}$ \\
\hline ECMO (hours) & $\begin{array}{l}237 \\
(\text { SD 208.61) }\end{array}$ & 504 (SD N/A) & - & 198.85 (SD 192.85) & $\begin{array}{l}0.189 \\
\text { N/A }\end{array}$ \\
\hline $\begin{array}{l}\text { Mortality / total } \\
\text { patients }\end{array}$ & $27.60 \%(396)$ & $37.40 \%(98)$ & $24.07 \%(103)$ & $26.17 \%(195)$ & $\begin{array}{l}0.001 \\
0.001 \\
0.424 \\
0.001\end{array}$ \\
\hline $\begin{array}{l}\text { Mortality / } \\
\text { Mechanical } \\
\text { ventilation }\end{array}$ & $56.07 \%(305 / 544)$ & $57.78 \%(78 / 135)$ & $59.38 \%(76 / 128)$ & $53.74 \%(151 / 281)$ & $\begin{array}{l}0.510 \\
\text { N/A }\end{array}$ \\
\hline $\begin{array}{l}\text { Mortality / ICU } \\
\text { patients }\end{array}$ & $39.83 \%(333 / 836)$ & $52.20 \%(83 / 159)$ & $36.18 \%(89 / 246)$ & $37.35 \%(161 / 431)$ & $\begin{array}{l}0.002 \\
0.001 \\
0.760 \\
0.001\end{array}$ \\
\hline \multicolumn{6}{|c|}{$\begin{array}{l}\text { *Each cell contains four p-values. } \\
\text { The first p'value corresponds to chi-squared test (for categorical variables) or one-way ANOVA test (for } \\
\text { numerical variables). Only a } p \leq 0.016 \text { was considered statistically significance. }\end{array}$} \\
\hline
\end{tabular}


medRxiv preprint doi: https://doi.org/10.1101/2022.01.10.22269002; this version posted January 11, 2022. The copyright holder BAtthis preprint (which was not certified by peer review) is the author/funder, who has granted medRxiv a license to display the preprint in It is made available under a CC-BY-NC-ND 4.0 International license .

RV: right ventricular; LV: left ventricular; ICU: intensive care unit; Prone: pronation; CPAP: Continuous Positive Airway Pressure; ECMO: Extracorporeal membrane oxygenation. 
medRxiv preprint doi: https://doi.org/10.1101/2022.01.10.22269002; this version posted January 11, 2022. The copyright holder 85 this preprint (which was not certified by peer review) is the author/funder, who has granted medRxiv a license to display the preprint in It is made available under perpetuity.

perpetuity. 
medRxiv preprint doi: https://doi.org/10.1101/2022.01.10.22269002; this version posted January 11, 2022. The copyright holder B6this preprint (which was not certified by peer review) is the author/funder, who has granted medRxiv a license to display the preprint in It is made available under a CC-BY-NC-ND 4.0 International license . 
medRxiv preprint doi: https://doi.org/10.1101/2022.01.10.22269002; this version posted January 11, 2022. The copyright holder 87 this preprint (which was not certified by peer review) is the author/funder, who has granted medRxiv a license to display the preprint in It is made available under perpetuity.

perpetuity. 
Figure I. RIMAC Registry: Participating regions, countries and institutions (1435 patients) medRxiv preprint doi: https://doi.org/10.1101/2022.011 10.22269002; this version posted January 11,2022 . The copyright holder for this
preprint (which was not certified by peer review) is the auth $\$ r$ /funder, who has granted medRxiv a license to display the preprint in It is made available under a $C$ C

\section{Mexico (262 patients)}



Instituto Nacional de Ciencias Médicas y Nutrición "Salvador Zubirán"

Centro Médico Nacional 20 de Noviembre

Hospital General de Zona Número 4, Monterrey

Central America \& Caribbean (428 patients):

\section{Guatemala}

TECNISCAN Hospitalia, Ciudad de Guatemala

\section{Panama}

Complejo Hospitalario Dr Arnulfo Arias Madrid, Ciudad de Panamá

\section{Dominican Republic}

CEDIMAT, Santo Domingo

South America (745 patients):

\section{Argentina}

Hospital El Cruce, Buenos Aires

\section{Brazil}

Hospital Israelita Albert Einstein, Sao Paulo Hospital Nossa Senhora das Graças y Universidade Federal do Paraná

\section{Chile}

Clinica Dávila, Santiago de Chile

\section{Colombia}

Hospital General de Medellín

\section{Peru}

Hospital Nacional Guillermo Almenara Irigoyen, Lima 
medRxiv preprint doi: https://doi.org/10.1101/2022.01.10.22269002; this version posted January 11, 2022. The copyright holder for this preprint (which was not certified by peer review) is the author/funder, who has granted medRxiv a license to display the preprint in

It is made available under a CC-BY-NC-ND 4.0 International license .

PATIENTS INCLUDED BY MONTH ( Year 2020)

300

00
0

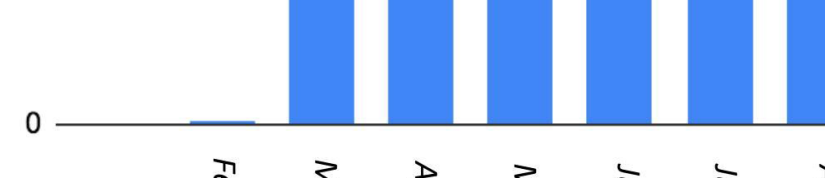
$\frac{\substack{2 \\ \frac{2}{2}}}{\frac{1}{2}}$

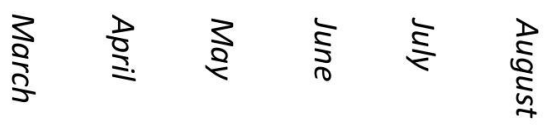

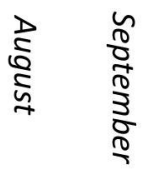
$\begin{array}{cc}2 & 3 \\ 0 & 0 \\ 0 & 0 \\ 0 & 0 \\ 0 & 0 \\ 0 & 0 \\ 0 & 0\end{array}$
$\begin{array}{ll}1 & 1 \\ 0 & 0 \\ 0 & 0 \\ 0 & 0 \\ 0 & 0 \\ 0 & 0 \\ 3 & 0 \\ 0 & 0 \\ 0 & 0\end{array}$

Figure II: Patients included from February to December 2020 (1435) 


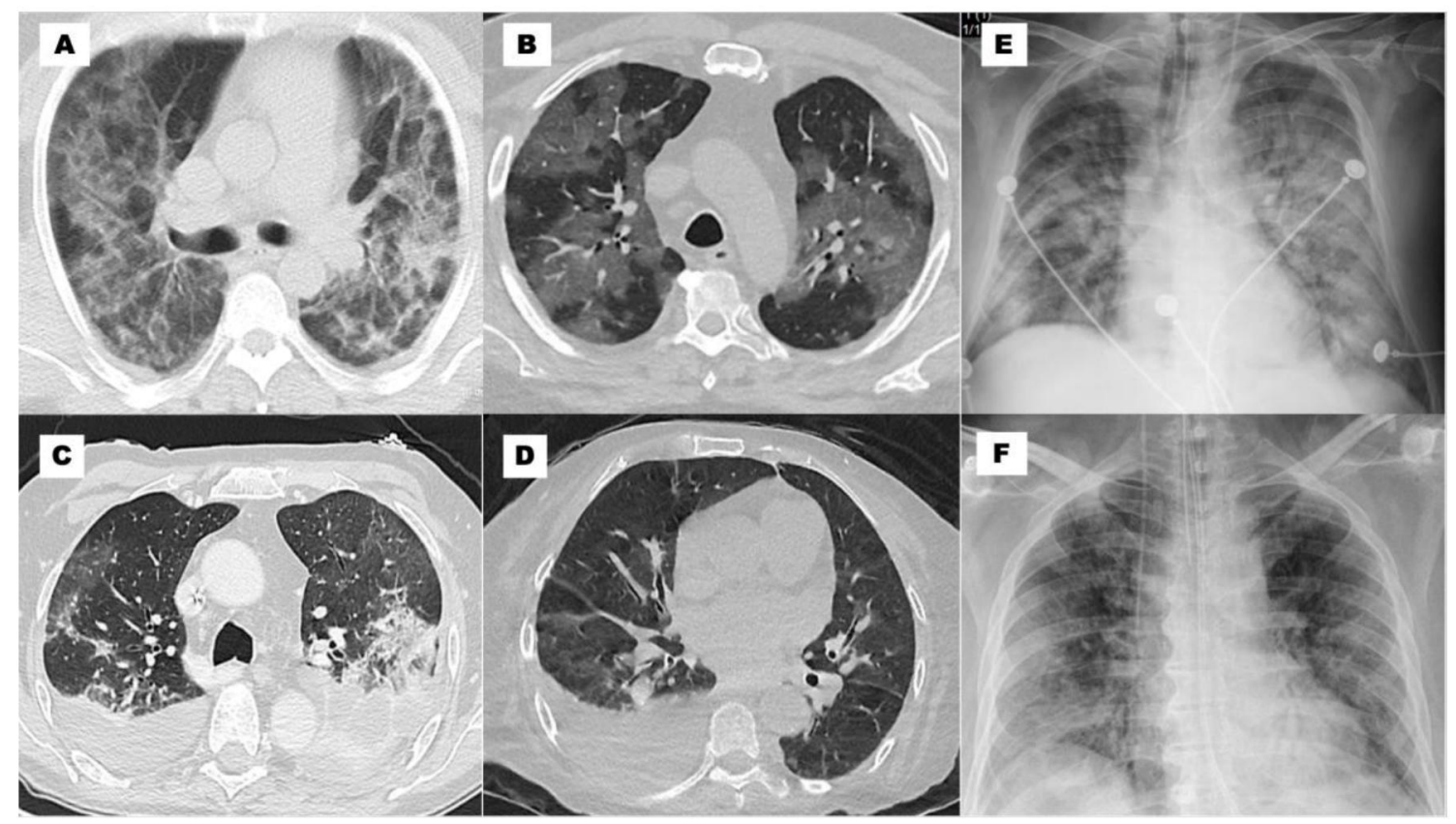

Figure III: Image Patterns. A: cTC: infiltrates in ground glass $>50 \%$, crazy paving and alveolar consolidation bilateral; B: cTC: infiltrates in ground glass > 50\% bilateral; C: cTC: infiltrates in ground glass $25-50 \%$ and pleural effusion bilateral; D: cTC: infiltrates in ground glass $<25 \%$ and pleural effusion unilateral; E: cX-ray: peripheral, basal and hilar infiltrates, ground glass pattern and consolidation; F: cX-ray: basal, and peripheral infiltrates, and ground glass pattern. 
Table 1: Demographic variables and baseline Comorbidities

\begin{tabular}{|l|l|l|l|l|l|}
\hline \multicolumn{2}{|c|}{ Demographic variables } \\
\end{tabular}

\section{Baseline Comorbilities}

\begin{tabular}{|c|c|c|c|c|c|}
\hline $\begin{array}{l}\text { Overweight/obesity } \\
(\mathrm{BMI} \geq 25)\end{array}$ & $61.25 \%(879)$ & $80.92 \%(212)$ & $64.95 \%(278)$ & $52.21 \%(389)$ & $\begin{array}{l}0.001 \\
0.001 \\
0.001 \\
0.001\end{array}$ \\
\hline $\begin{array}{l}\text { Overweight } \\
\text { (BMI } 25 \text { to 29) }\end{array}$ & $35.75 \%(513)$ & $38.55 \%(101)$ & $43.93 \%(188)$ & $30.07 \%(224)$ & $\begin{array}{l}0.001 \\
0.165 \\
0.001 \\
0.012\end{array}$ \\
\hline $\begin{array}{l}\text { Obesity } \\
(\text { BMI } \geq 30)\end{array}$ & $25.51 \%(366)$ & $42.37 \%(111)$ & $21.03 \%(90)$ & $22.15 \%(165)$ & $\begin{array}{l}0.001 \\
0.001 \\
0.654 \\
0.001\end{array}$ \\
\hline HBP & $45.37 \%(651)$ & $36.26 \%(95)$ & $60.28 \%(258)$ & $40.00 \%(298)$ & $\begin{array}{l}0.001 \\
0.001 \\
0.001 \\
0.286\end{array}$ \\
\hline DBT & $26.83 \%(385)$ & $34.35 \%(90)$ & $33.64 \%(144)$ & $20.27 \%(151)$ & $\begin{array}{l}0.001 \\
0.849 \\
0.001 \\
0.001\end{array}$ \\
\hline Ex tobacco use & $14.15 \%(203)$ & $6.87 \%(18)$ & $19.63 \%(84)$ & $13.56 \%(101)$ & $\begin{array}{l}0.001 \\
0.001 \\
0.006\end{array}$ \\
\hline
\end{tabular}




\begin{tabular}{|c|c|c|c|c|c|}
\hline & & & & & 0.004 \\
\hline Active tobacco use & $8.43 \%(121)$ & $13.74 \%(36)$ & $7.94 \%(34)$ & $6.85 \%(51)$ & $\begin{array}{l}0.002 \\
0.014 \\
0.485 \\
0.001\end{array}$ \\
\hline $\begin{array}{l}\text { Ischemic heart } \\
\text { disease }\end{array}$ & $6.76 \%(97)$ & $4.96 \%(13)$ & $9.58 \%(41)$ & $5.77 \%(43)$ & $\begin{array}{l}0.019 \\
0.028 \\
0.015 \\
0.623\end{array}$ \\
\hline COPD & $6.62 \%(95)$ & $2.67 \%(7)$ & $2.10 \%(9)$ & $10.60 \%(79)$ & $\begin{array}{l}0.001 \\
0.630 \\
0.001 \\
0.001\end{array}$ \\
\hline Renal failure & $4.32 \%(62)$ & $1.91 \%(5)$ & $2.80 \%(12)$ & $6.04 \%(45)$ & $\begin{array}{l}0.003 \\
0.462 \\
0.013 \\
0.008\end{array}$ \\
\hline Myocardiopathy & $4.74 \%(68)$ & $0.00 \%(0)$ & $9.11 \%(39)$ & $3.89 \%(29)$ & $\begin{array}{l}0.001 \\
0.001 \\
0.001 \\
0.001\end{array}$ \\
\hline $\begin{array}{l}\text { Valvular heart } \\
\text { disease }\end{array}$ & $1.74 \%(25)$ & $2.29 \%(6)$ & $2.57 \%(11)$ & $1.07 \%(8)$ & $\begin{array}{l}0.128 \\
\mathrm{~N} / \mathrm{A}\end{array}$ \\
\hline HIV & $0.42 \%(6)$ & $0.38 \%(1)$ & $0.00 \%(0)$ & $0.67 \%(5)$ & $\begin{array}{l}0.229 \\
\text { N/A }\end{array}$ \\
\hline \multicolumn{6}{|c|}{$\begin{array}{l}\text { *Each cell contains four } p \text {-values. } \\
\text { The first p-value corresponds to chi-squared test (for categorical variables) or one-way ANOVA tes } \\
\text { (for numerical variables). Only a } p \leq 0.016 \text { was considered statistically significance. } \\
\text { The second, third and fourth corresponds to multiple comparisons between groups: Mx and CAC, } \\
\text { CAC and SAm, SAm and Mx, respectively. We used multiple chi-squared tests and ANOVA with } \\
\text { Bonferroni correction. }\end{array}$} \\
\hline
\end{tabular}

HBP: Hight Blood Pressure; DBT: Diabetes; COPD: Chronic obstructive pulmonary disease; HIV: Human immunodeficiency virus 
Table 2: Image modalities used

\begin{tabular}{|c|c|c|c|c|c|}
\hline & $\begin{array}{l}\text { Global } \\
\text { (n: 1435) }\end{array}$ & $\begin{array}{l}\text { Mexico } \\
\quad(\mathrm{Mx}) \\
\text { (n: 262) }\end{array}$ & $\begin{array}{c}\text { Central } \\
\text { America and } \\
\text { Caribbean } \\
\text { (CAC) } \\
\text { (n: 428) }\end{array}$ & $\begin{array}{c}\text { Southamerica } \\
\text { (Sam) } \\
\text { (n: 745) }\end{array}$ & p-value \\
\hline $\begin{array}{l}\text { Chest computed } \\
\text { tomography } \\
\text { ( cCT ) }\end{array}$ & $61.53 \%(883)$ & $69.08 \%(181)$ & $32.24 \%(138)$ & $75.70 \%(564)$ & $\begin{array}{l}0.001 \\
0.001 \\
0.001 \\
0.036\end{array}$ \\
\hline $\begin{array}{l}\text { Chest R-ray } \\
\text { (cX-ray) }\end{array}$ & $45.99 \%(660)$ & $38.55 \%(101)$ & $91.12 \%(390)$ & $22.68 \%(169)$ & $\begin{array}{l}0.001 \\
0.001 \\
0.001 \\
0.001\end{array}$ \\
\hline $\begin{array}{l}\text { Echocardiogram } \\
\text { ( cEcho ) }\end{array}$ & $18.54 \%(266)$ & $24.43 \%(64)$ & $18.93 \%(81)$ & $16.24 \%(121)$ & $\begin{array}{l}0.013 \\
0.085 \\
0.241 \\
0.003\end{array}$ \\
\hline $\begin{array}{l}\text { Lung ultrasound } \\
\text { ( LUS ) }\end{array}$ & $7.25 \%(104)$ & $22.14 \%(58)$ & $0.23 \%(1)$ & $6.04 \%(45)$ & $\begin{array}{l}0.001 \\
0.001 \\
0.001 \\
0.001\end{array}$ \\
\hline $\begin{array}{l}\text { Electrocardiogram } \\
\text { ( ECG ) }\end{array}$ & $24.32 \%(349)$ & $41.22 \%(108)$ & $37.62 \%(161)$ & $10.74 \%(80)$ & $\begin{array}{l}0.001 \\
0.346 \\
0.001 \\
0.001\end{array}$ \\
\hline \multicolumn{6}{|c|}{$\begin{array}{l}\text { *Each cell contains four } p \text {-values. } \\
\text { The first p'value corresponds to chi-squared test (for categorical variables) or one-way ANOVA test } \\
\text { (for numerical variables). Only a } p \leq 0.016 \text { was considered statistically significance. } \\
\text { The second, third and fourth corresponds to multiple comparisons between groups: Mx and CAC, } \\
\text { CAC and SAm, SAm and Mx, respectively. We used multiple chi-squared tests and ANOVA with } \\
\text { Bonferroni correction. }\end{array}$} \\
\hline
\end{tabular}


Table 3: Images used and confounders: multivariate analysis

\begin{tabular}{|c|c|c|c|c|c|c|c|c|}
\hline & \multicolumn{2}{|c|}{ Zone 1 (Mx) } & \multicolumn{3}{|c|}{ Zone 2 (CAC) } & \multicolumn{3}{|c|}{ Zone 3 (SAm) } \\
\hline & $\mathrm{n}: 262$ & crude OR & $n: 428$ & $\begin{array}{c}\text { crude OR } \\
(95 \% \mathrm{Cl})\end{array}$ & $\begin{array}{c}\text { adjusted } \\
\mathrm{OR}^{\star}(95 \% \mathrm{Cl})\end{array}$ & $\mathrm{n}: 745$ & $\begin{array}{c}\text { crude OR } \\
(95 \% \mathrm{Cl})\end{array}$ & $\begin{array}{l}\text { adjusted } \mathrm{OR}^{*} \\
(95 \% \mathrm{Cl})\end{array}$ \\
\hline $\begin{array}{l}\text { Chest computed } \\
\text { tomography } \\
\text { ( cCT ) }\end{array}$ & $69.08 \%(181)$ & Baseline & $32.24 \%(138)$ & $\begin{array}{l}0.21 \\
(0-15-0.29)\end{array}$ & $\begin{array}{l}0.19 \\
(0.13-.27)\end{array}$ & $\begin{array}{l}75.70 \% \\
(564)\end{array}$ & $\begin{array}{l}1.39 \\
(1.02-1.90)\end{array}$ & $\begin{array}{l}1.54 \\
(1.10-2.16)\end{array}$ \\
\hline $\begin{array}{l}\text { Electrocardiogram } \\
\text { ( ECG ) }\end{array}$ & $41.22 \%(108)$ & Baseline & $37.62 \%(161)$ & $\begin{array}{l}0.85 \\
(0.62-1.17)\end{array}$ & \begin{tabular}{|l}
0.68 \\
$(0.48-0.96)$
\end{tabular} & $\begin{array}{l}10.74 \% \\
(80)\end{array}$ & $\begin{array}{l}0.17 \\
(0.12-0.24)\end{array}$ & $\begin{array}{l}0.14 \\
(0.09-0.20)\end{array}$ \\
\hline $\begin{array}{l}\text { Echocardiogram } \\
\text { ( cEcho ) }\end{array}$ & $24.43 \%(64)$ & Baseline & $18.93 \%(81)$ & $\begin{array}{l}0.72 \\
(0.49-1.04)\end{array}$ & \begin{tabular}{|l}
0.82 \\
$(0.55-1.23)$
\end{tabular} & $\begin{array}{l}16.24 \% \\
(121)\end{array}$ & $\begin{array}{l}0.59 \\
(0.42-0.84)\end{array}$ & $\begin{array}{l}0.68 \\
(0.47-.99)\end{array}$ \\
\hline $\begin{array}{l}\text { Lung ultrasound } \\
\text { ( LUS ) }\end{array}$ & $22.14 \%(58)$ & Baseline & $0.23 \%(1)$ & $\begin{array}{l}0.01 \\
(0.01-0.05)\end{array}$ & $\begin{array}{l}0.01 \\
(0.01-.06)\end{array}$ & $6.04 \%(45)$ & $\begin{array}{l}0.22 \\
(0.14-0.34)\end{array}$ & $\begin{array}{l}0.29 \\
(0.18-0.47)\end{array}$ \\
\hline
\end{tabular}


Table 4: Image Patterns Global and Regions

\begin{tabular}{|c|c|c|c|c|c|}
\hline & $\begin{array}{l}\text { Global } \\
\text { (n: 1435) }\end{array}$ & $\begin{array}{c}\text { Mexico } \\
(\mathrm{Mx}) \\
(\mathrm{n}: 262)\end{array}$ & $\begin{array}{l}\text { Central America } \\
\text { and Caribbean } \\
\text { (CAC) } \\
\text { (n: 428) }\end{array}$ & $\begin{array}{l}\text { Southamerica } \\
\text { (SAm) } \\
\text { (n: 745) }\end{array}$ & p-value* \\
\hline $\begin{array}{l}\text { CHEST COMPUTED } \\
\text { TOMOGRAPHY } \\
\text { ( } \mathrm{CCT} \text { ) }\end{array}$ & $61.53 \%(883)$ & 69.08\% (181) & $32.24 \%(\mathbf{1 3 8})$ & $75.70 \%(564)$ & $\begin{array}{l}0.001 \\
0.001 \\
0.001 \\
0.036\end{array}$ \\
\hline Infiltrates in ground glass & $89.35 \%(789 / 883)$ & $99.45 \%(180)$ & $87.68 \%(121)$ & $86.52 \%(488)$ & $\begin{array}{l}0.001 \\
0.001 \\
0.719 \\
0.001\end{array}$ \\
\hline $\begin{array}{l}\text { Infiltrates, } \% \\
\qquad \begin{array}{r}25-50 \% \\
<25 \% \\
>50 \%\end{array}\end{array}$ & $\begin{array}{l}32.95 \%(260 / 789) \\
21.29 \%(168 / 789) \\
45.75 \%(361 / 789)\end{array}$ & $\begin{array}{l}18.33 \%(33) \\
13.33 \%(24) \\
68.33 \%(123)\end{array}$ & $\begin{array}{l}41.32 \%(50) \\
33.06 \%(40) \\
25.62 \%(31)\end{array}$ & $\begin{array}{l}36.27 \%(177) \\
21.31 \%(104) \\
42.42 \%(207)\end{array}$ & $\begin{array}{l}0.001 \\
N / A\end{array}$ \\
\hline Crazy Paving & $30.01 \%(618 / 883)$ & $20.99 \%(38)$ & $45.65 \%(63)$ & $29.08 \%(164)$ & $\begin{array}{l}0.001 \\
0.001 \\
0.001 \\
0.033\end{array}$ \\
\hline Alveolar Consolidation & $36.58 \%(323 / 883)$ & $35.36 \%(64)$ & $42.75 \%(59)$ & $35.46 \%(200)$ & $\begin{array}{l}0.261 \\
N / A\end{array}$ \\
\hline Pleural Effusion & $10.76 \%(95 / 883)$ & $12.71 \%(23)$ & $18.84 \%(26)$ & $8.16 \%(46)$ & 0.001 \\
\hline
\end{tabular}




\begin{tabular}{|c|c|c|c|c|c|}
\hline & & & & & $\begin{array}{l}0.132 \\
0.001 \\
0.066\end{array}$ \\
\hline $\begin{array}{l}\text { CHEST R-RAY } \\
\text { ( cX-ray) }\end{array}$ & $45.99 \%(660)$ & $38.55 \%(101)$ & $91.12 \%(390)$ & $22.68 \%(169)$ & $\begin{array}{l}0.001 \\
0.001 \\
0.001 \\
0.001\end{array}$ \\
\hline Basal Infiltrates & $51.97 \%(343 / 660)$ & $83.17 \%(84)$ & $41.28 \%(161)$ & $57.99 \%(98)$ & $\begin{array}{l}0.001 \\
0.001 \\
0.001 \\
0.001\end{array}$ \\
\hline Peripheral Infiltrates & $63.33 \%(418 / 660)$ & $89.11 \%(90)$ & $58.97 \%(230)$ & $57.99 \%(98)$ & $\begin{array}{l}0.001 \\
0.001 \\
0.828 \\
0.001\end{array}$ \\
\hline Hilar Infiltrates & $39.24 \%(259 / 660)$ & $54.46 \%(55)$ & $44.87 \%(175)$ & $17.16 \%(29)$ & $\begin{array}{l}0.001 \\
0.085 \\
0.001 \\
0.001\end{array}$ \\
\hline Ground Glass pattern & $45.00 \%(297 / 660)$ & $74.26 \%(75)$ & $43.59 \%(170)$ & $30.77 \%(52)$ & $\begin{array}{l}0.001 \\
0.001 \\
0.004 \\
0.004\end{array}$ \\
\hline Consolidation & $25.15 \%(166 / 660)$ & $57.43 \%(58)$ & $19.23 \%(75)$ & $19.53 \%(33)$ & $\begin{array}{l}0.001 \\
0.001 \\
0.935\end{array}$ \\
\hline
\end{tabular}




\begin{tabular}{|c|c|c|c|c|c|}
\hline & & & & & 0.001 \\
\hline $\begin{array}{l}\text { ECHOCARDIOGRAM } \\
\text { ( cEcho ) }\end{array}$ & $18.54 \%(266)$ & $24.43 \%(64)$ & $18.93 \%(81)$ & $16.24 \%(\mathbf{1 2 1})$ & $\begin{array}{l}0.013 \\
0.085 \\
0.241 \\
0.003\end{array}$ \\
\hline $\begin{array}{l}\text { Left ventricular ejection } \\
\text { fraction } \\
\text { (LVEF) } \\
\text { (n: 266) }\end{array}$ & 56.89 (SD 11.89) & 57.40 (SD 9.78) & 54.48 (SD 13.97) & 58.23 (SD 11.22) & $\begin{array}{l}0.008 \\
0.421 \\
0.083 \\
1.000\end{array}$ \\
\hline $\begin{array}{l}\text { Right ventricular fractional } \\
\text { area } \\
\text { (FaRV) } \\
\text { (n: 166) }\end{array}$ & 38.17 (SD 10.61) & 34.71 (SD 7.87) & 30.33 (SD 6.80) & $40.20($ SD 11.41) & $\begin{array}{l}0.002 \\
1.000 \\
0.311 \\
0.004\end{array}$ \\
\hline $\begin{array}{l}\text { Left ventricular global } \\
\text { longitudinal strain } \\
\text { (GLS LV) } \\
\text { (n: } 57)\end{array}$ & -17.31 (SD 5.18) & $-13(\mathrm{SD} 0)$ & $-11.2($ SD 3.65$)$ & -18.74 (SD 4.47) & $\begin{array}{l}0.001 \\
1.000 \\
0.001 \\
0.591\end{array}$ \\
\hline $\begin{array}{l}\text { Right ventricular free wall } \\
\text { strain } \\
\text { (FWSRV) } \\
\text { (n: 18) }\end{array}$ & -24.85 (SD 6.85) & -15 (SD 0) & $\mathrm{N} / \mathrm{A}$ & $-25.42(\mathrm{SD} 6.60)$ & 0.144 \\
\hline $\begin{array}{l}\text { Trans-mitral Pattern } \\
\text { LV impaired relaxation } \\
\text { Atrial Fibrillation } \\
\text { Normal } \\
\text { Restrictive pattern } \\
\text { Seudonormal pattern }\end{array}$ & $\begin{array}{l}41.73 \%(111 / 266) \\
7.89 \%(21 / 266) \\
42.48 \%(113 / 266) \\
2.63 \%(7 / 266) \\
5.26 \%(14 / 266)\end{array}$ & $\begin{array}{l}68.75 \%(44) \\
3.12 \%(2) \\
26.56 \%(17) \\
0.00 \%(0) \\
1.56 \%(1)\end{array}$ & $\begin{array}{l}30.86 \%(25) \\
4.94 \%(4) \\
51.85 \%(42) \\
4.94 \%(4) \\
7.41 \%(6)\end{array}$ & $\begin{array}{l}34.71 \%(42) \\
12.40 \%(15) \\
44.63 \%(54) \\
2.48 \%(3) \\
5.79 \%(7)\end{array}$ & $\begin{array}{l}0.001 \\
N / A\end{array}$ \\
\hline
\end{tabular}




\begin{tabular}{|c|c|c|c|c|c|}
\hline Abnormal motility & $15.79 \%(42 / 266)$ & $9.38 \%(6)$ & $25.93 \%(21)$ & $12.40 \%(15)$ & $\begin{array}{l}0.010 \\
0.011 \\
0.014 \\
0.538\end{array}$ \\
\hline Pericardial Effusion & $10.90 \%(29)$ & $3.12 \%(2)$ & $4.94 \%(4)$ & $19.01 \%(23)$ & $\begin{array}{l}0.001 \\
0.586 \\
0.004 \\
0.003\end{array}$ \\
\hline $\begin{array}{l}\text { LUNG ULTRASOUND } \\
\text { ( LUS ) }\end{array}$ & $7.25 \%(104)$ & $22.14 \%(58)$ & $0.23 \%(\mathbf{1})$ & $6.04 \%(45)$ & $\begin{array}{l}0.001 \\
0.001 \\
0.001 \\
0.001\end{array}$ \\
\hline Interstitial Syndrome & $55.77 \%(58 / 104)$ & $96.55 \%(56)$ & $100.00 \%(1)$ & $2.22 \%(1)$ & $\begin{array}{l}0.001 \\
0.850 \\
0.001 \\
0.001\end{array}$ \\
\hline Consolidation & $25.15 \%(166 / 104)$ & $47.83 \%(11)$ & $0.00 \%(0)$ & $0.00 \%(0)$ & $\begin{array}{l}0.426 \\
N / A\end{array}$ \\
\hline Pleural Effusion & $9.62 \%(10 / 104)$ & $5.17 \%(3)$ & $0.00 \%(0)$ & $15.56 \%(7)$ & $\begin{array}{l}0.197 \\
\text { N/A }\end{array}$ \\
\hline \multicolumn{6}{|c|}{$\begin{array}{l}\text { *Each cell contains four } p \text {-values. } \\
\text { The first p'value corresponds to chi-squared test (for categorical variables) or one-way ANOVA test (for numerical variables). Only } \\
\text { a } p \leq 0.016 \text { was considered statistically significance. }\end{array}$} \\
\hline
\end{tabular}


The second, third and fourth corresponds to multiple comparisons between groups: Mx and CAC, CAC and SAm, SAm and Mx, respectively. We used multiple chi-squared tests and ANOVA with Bonferroni correction. 
Table 5: Modalities imaging logistic regression associated with comorbidities, complications and evolution

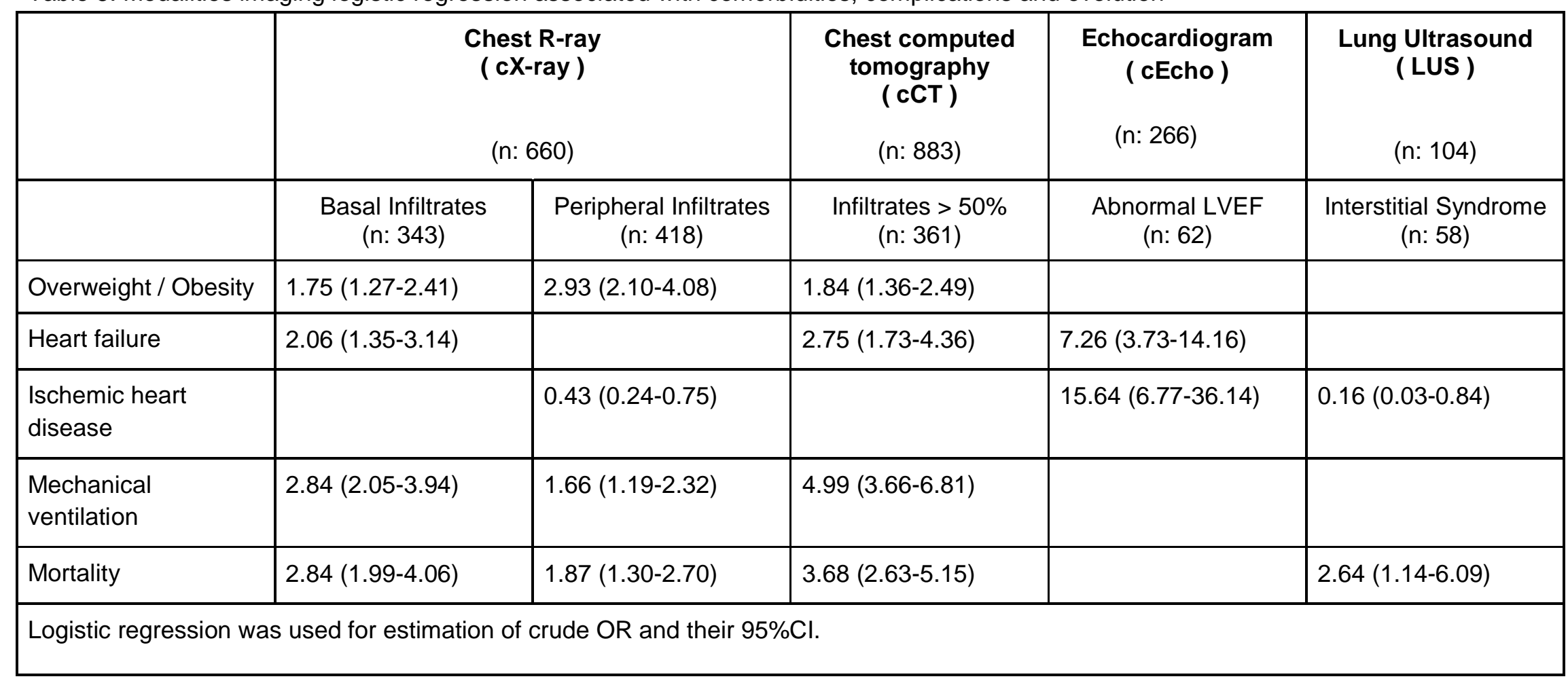

LVEF: left ventricular ejection fraction; OR: Odds ratio; Cl: confidence interval 
Table 6: Complications and Evolution

\begin{tabular}{|c|c|c|c|c|c|}
\hline & $\begin{array}{l}\text { Global } \\
\text { (n: 1435) }\end{array}$ & $\begin{array}{l}\begin{array}{c}\text { Mexico } \\
\text { (Mx) }\end{array} \\
\text { (n: 262) }\end{array}$ & $\begin{array}{c}\text { Central } \\
\text { America and } \\
\text { Caribbean } \\
\text { (CAC) } \\
(\mathrm{n}: \mathbf{4 2 8})\end{array}$ & $\begin{array}{l}\text { Southamerica } \\
\text { (SAm) } \\
\text { (n: } 745)\end{array}$ & p-value* \\
\hline \multicolumn{6}{|l|}{ Complications } \\
\hline Renal Failure & $20.14 \%$ (289 & $22.52 \%(59)$ & $13.32 \%(57)$ & $23.22 \%(173)$ & $\begin{array}{l}0.001 \\
0.002 \\
0.001 \\
0.816\end{array}$ \\
\hline $\begin{array}{l}\text { Heart Failure } \\
\text { RV } \\
\text { LV } \\
\text { RV + LV }\end{array}$ & $\begin{array}{l}13.13 \%(191) \\
\\
20.41 \%(39 / 191) \\
45.54 \%(87 / 191) \\
34.05 \%(65 / 191)\end{array}$ & $16.79 \%(44)$ & $19.86 \%(85)$ & $8.32 \%(62)$ & $\begin{array}{l}0.001 \\
0.316 \\
0.001 \\
0.001\end{array}$ \\
\hline Cardiac arrest & $4.81 \%(69)$ & $0.76 \%(2)$ & $9.58 \%(41)$ & $3.49 \%(26)$ & $\begin{array}{l}0.001 \\
0.001 \\
0.001 \\
0.021\end{array}$ \\
\hline $\begin{array}{l}\text { Myocardial } \\
\text { Infarction }\end{array}$ & $4.04 \%(58)$ & $2.29 \%(6)$ & $7.94 \%(34)$ & $2.42 \%(18)$ & $\begin{array}{l}0.001 \\
0.002 \\
0.001 \\
0.908\end{array}$ \\
\hline Myocarditis & $3.41 \%(49)$ & $3.44 \%(9)$ & $7.71 \%(33)$ & $0.94 \%(7)$ & $\begin{array}{l}0.001 \\
0.023 \\
0.001 \\
0.005\end{array}$ \\
\hline $\begin{array}{l}\text { Lung } \\
\text { Thromboembolism }\end{array}$ & $3.34 \%(48)$ & $10.69 \%(28)$ & $1.40 \%(6)$ & $1.88 \%(14)$ & $\begin{array}{l}0.001 \\
0.001 \\
0.543 \\
0.001\end{array}$ \\
\hline $\begin{array}{l}\text { Deep Venous } \\
\text { Thrombosis }\end{array}$ & $0.56 \%(8)$ & $0.38 \%(1)$ & $0.70 \%(3)$ & $0.54 \%(4)$ & $\begin{array}{l}0.856 \\
\text { N/A }\end{array}$ \\
\hline Takotsubo & $0.21 \%(3)$ & $0.38 \%(1)$ & $0.23 \%(1)$ & $0.13 \%(1)$ & $\begin{array}{l}0.746 \\
\text { N/A }\end{array}$ \\
\hline
\end{tabular}




\begin{tabular}{|c|c|c|c|c|c|}
\hline \multicolumn{6}{|l|}{ Evolution } \\
\hline WARD admission & $49.34 \%(708)$ & $61.07 \%(160)$ & $47.90(205)$ & $46.04 \%(343)$ & $\begin{array}{l}0.001 \\
0.001 \\
0.539 \\
0-001\end{array}$ \\
\hline ICU admission & $50.66 \%(727)$ & $38.93 \%(102)$ & $52.10 \%(223)$ & $53.96 \%(402)$ & $\begin{array}{l}0.001 \\
0.001 \\
0.539 \\
0.001\end{array}$ \\
\hline $\begin{array}{l}\text { ICU during } \\
\text { hospitaization }\end{array}$ & $58.26 \%(836)$ & $60.69 \%(159)$ & $57.48 \%(246)$ & $57.85 \%(431)$ & $\begin{array}{l}0.672 \\
N / A\end{array}$ \\
\hline $\begin{array}{l}\text { Hospitalization } \\
\text { Days }\end{array}$ & 17.49 (SD 17.24) & $16.01(S D 261)$ & $15.39(\mathrm{SD} 16.04)$ & 19.21 (SD 19.02) & $\begin{array}{l}0.001 \\
1.000 \\
0.001 \\
0.028\end{array}$ \\
\hline ICU Days & 13.56 (SD 14.2) & 13.35 (SD12.68) & 7.94 (SD 8.36) & 16.73 (SD 16.09) & $\begin{array}{l}0.001 \\
0.003 \\
0.001 \\
0.079\end{array}$ \\
\hline $\begin{array}{l}\text { Mechanical } \\
\text { ventilation / total } \\
\text { patients }\end{array}$ & $37.91 \%(544)$ & $51.53 \%(135)$ & $29.91 \%(128)$ & $37.72 \%(281)$ & $\begin{array}{l}0.001 \\
0.001 \\
0.007 \\
0.001\end{array}$ \\
\hline $\begin{array}{l}\text { Mechanical } \\
\text { ventilation / ICU } \\
\text { patients }\end{array}$ & $\begin{array}{l}65.07 \% \\
(544 / 836)\end{array}$ & $\begin{array}{l}84.91 \% \\
(135 / 159)\end{array}$ & $\begin{array}{l}52.03 \% \\
(128 / 246)\end{array}$ & $65.20 \%(281 / 431)$ & $\begin{array}{l}0.001 \\
0.001 \\
0.001 \\
0.001\end{array}$ \\
\hline $\begin{array}{l}\text { Mechanical } \\
\text { ventilation duration } \\
\text { (hours) }\end{array}$ & $\begin{array}{l}356.61 \\
\text { (SD 298.12) }\end{array}$ & $\begin{array}{l}308.26 \\
\text { (SD 271.15) }\end{array}$ & $\begin{array}{l}241.89 \\
\text { (SD 198.75) }\end{array}$ & $\begin{array}{l}432.11 \\
\text { (SD 326.17) }\end{array}$ & $\begin{array}{l}0.001 \\
0.185 \\
0.001 \\
0.001\end{array}$ \\
\hline $\begin{array}{l}\text { Mechanical } \\
\text { ventilation duration } \\
\text { (days) }\end{array}$ & 14.85 (SD 12.42) & $\begin{array}{l}12.84(\mathrm{SD} \\
11.29)\end{array}$ & 10.07 (SD 8.28) & 18.01 (SD 13.59) & $\begin{array}{l}0.001 \\
0.185 \\
0.001 \\
0.001\end{array}$ \\
\hline $\begin{array}{l}\text { Prone / total } \\
\text { patients }\end{array}$ & $22.37 \%(321)$ & $41.98 \%(110)$ & $7.24 \%(31)$ & $24.16 \%(180)$ & $\begin{array}{l}0.001 \\
0.001 \\
0.007\end{array}$ \\
\hline
\end{tabular}




\begin{tabular}{|c|c|c|c|c|c|}
\hline & & & & & 0.001 \\
\hline $\begin{array}{l}\text { Prone / ICU } \\
\text { patients }\end{array}$ & $\begin{array}{l}37.80 \% \\
(316 / 836)\end{array}$ & $\begin{array}{l}67.30 \% \\
(107 / 159)\end{array}$ & $11.79 \%(29 / 246)$ & $41.76 \%(180 / 431)$ & $\begin{array}{l}0.001 \\
0.001 \\
0.001 \\
0.001\end{array}$ \\
\hline $\begin{array}{l}\text { Prone / } \\
\text { Mechanical } \\
\text { ventilation }\end{array}$ & $\begin{array}{l}50.18 \% \\
(273 / 544)\end{array}$ & $72.59 \%(98 / 135)$ & $18.75 \%(24 / 128)$ & $53.74 \%(151 / 281)$ & $\begin{array}{l}0.001 \\
0.001 \\
0.001 \\
0.001\end{array}$ \\
\hline $\begin{array}{l}\text { Prone duration } \\
\text { (hours) }\end{array}$ & $\begin{array}{l}137.09 \\
\text { (SD 94.74) }\end{array}$ & $\begin{array}{l}141.6 \\
\text { (SD 91.19) }\end{array}$ & $\begin{array}{l}61.93 \\
\text { (SD 56.71) }\end{array}$ & $\begin{array}{l}147.28 \\
\text { (SD 96.68) }\end{array}$ & $\begin{array}{l}0.004 \\
0.001 \\
0.001 \\
1.000\end{array}$ \\
\hline $\begin{array}{l}\text { CPAP / total } \\
\text { patients }\end{array}$ & $13.17 \%(189)$ & $12.21 \%(32)$ & $10.28 \%(44)$ & $15.17 \%(113)$ & $\begin{array}{l}0.051 \\
N / A\end{array}$ \\
\hline $\begin{array}{l}\text { CPAP / } \\
\text { Mechanical } \\
\text { ventilation }\end{array}$ & $17.83 \%(97 / 544)$ & $9.63 \%(13 / 135)$ & $13.28 \%(17 / 128)$ & $23.84 \%(67 / 281)$ & 0.001 \\
\hline $\begin{array}{l}\text { CPAP duration } \\
\text { (hours) }\end{array}$ & $\begin{array}{l}120.42 \\
\text { (SD 120.63) }\end{array}$ & $\begin{array}{l}98.25 \\
\text { (SD 93.32) }\end{array}$ & $\begin{array}{l}83.45 \\
\text { (SD 96.48) }\end{array}$ & $\begin{array}{l}141.10 \\
\text { (SD 131.65) }\end{array}$ & $\begin{array}{l}0.012 \\
1.000 \\
0.020 \\
0.218\end{array}$ \\
\hline Nasal cannula & $49.69 \%(713)$ & $66.41 \%(174)$ & $49.07 \%(210)$ & $44.16 \%(329)$ & $\begin{array}{l}0.001 \\
0.001 \\
0.105 \\
0.001\end{array}$ \\
\hline $\begin{array}{l}\text { Nasal cannula } \\
\text { duration (hours) }\end{array}$ & $\begin{array}{l}150.90 \\
\text { (SD 149.49) }\end{array}$ & $\begin{array}{l}214.20 \\
\text { (SD 161.48) }\end{array}$ & $\begin{array}{l}80.11 \\
\text { (SD 76.38) }\end{array}$ & $\begin{array}{l}162.60 \\
\text { (SD 159.90) }\end{array}$ & $\begin{array}{l}0.001 \\
0.001 \\
0.001 \\
0.001\end{array}$ \\
\hline ECMO & $0.56 \%(8)$ & $0.38 \%(1)$ & $0.00 \%(0)$ & $0.94 \%(7)$ & $\begin{array}{l}0.105 \\
N / A\end{array}$ \\
\hline ECMO (hours) & $\begin{array}{l}237 \\
\text { (SD 208.61) }\end{array}$ & 504 (SD N/A) & - & $\begin{array}{l}198.85 \text { (SD } \\
192.85)\end{array}$ & $\begin{array}{l}0.189 \\
N / A\end{array}$ \\
\hline $\begin{array}{l}\text { Mortality / total } \\
\text { patients }\end{array}$ & $27.60 \%(396)$ & $37.40 \%(98)$ & $24.07 \%(103)$ & $26.17 \%(195)$ & $\begin{array}{l}0.001 \\
0.001 \\
0.424 \\
0.001\end{array}$ \\
\hline
\end{tabular}




\begin{tabular}{|c|c|c|c|c|c|}
\hline $\begin{array}{l}\text { Mortality / } \\
\text { Mechanical } \\
\text { ventilation }\end{array}$ & $\begin{array}{l}56.07 \% \\
(305 / 544)\end{array}$ & $57.78 \%(78 / 135)$ & $59.38 \%(76 / 128)$ & $53.74 \%(151 / 281)$ & $\begin{array}{l}0.510 \\
\text { N/A }\end{array}$ \\
\hline $\begin{array}{l}\text { Mortality / ICU } \\
\text { patients }\end{array}$ & $\begin{array}{l}39.83 \% \\
(333 / 836)\end{array}$ & $52.20 \%(83 / 159)$ & $36.18 \%(89 / 246)$ & $37.35 \%(161 / 431)$ & $\begin{array}{l}0.002 \\
0.001 \\
0.760 \\
0.001\end{array}$ \\
\hline \multicolumn{6}{|c|}{$\begin{array}{l}\text { "Each cell contains four p-values. } \\
\text { The first p'value corresponds to chi-squared test (for categorical variables) or one-way ANOVA test (for } \\
\text { numerical variables). Only a } p \leq 0.016 \text { was considered statistically significance. } \\
\text { The second, third and fourth corresponds to multiple comparisons between groups: Mx and CAC, CAC and } \\
\text { SAm, SAm and Mx, respectively. We used multiple chi-squared tests and ANOVA with Bonferroni correction. }\end{array}$} \\
\hline
\end{tabular}

RV: right ventricular; LV: left ventricular; ICU: intensive care unit; Prone: pronation; CPAP: Continuous Positive Airway Pressure; ECMO: Extracorporeal membrane oxygenation. 